Florida International University FIU Digital Commons

7-18-2002

\title{
Fear and U.S. foreign policy during the Truman administration, 1945-1952
}

Jessica Rose Barrella

Florida International University

DOI: $10.25148 /$ etd.FI14050436

Follow this and additional works at: https://digitalcommons.fiu.edu/etd

Part of the History Commons

\section{Recommended Citation}

Barrella, Jessica Rose, "Fear and U.S. foreign policy during the Truman administration, 1945-1952" (2002). FIU Electronic Theses and Dissertations. 1404.

https://digitalcommons.fiu.edu/etd/1404

This work is brought to you for free and open access by the University Graduate School at FIU Digital Commons. It has been accepted for inclusion in FIU Electronic Theses and Dissertations by an authorized administrator of FIU Digital Commons. For more information, please contact dcc@fiu.edu. 


\section{FLORIDA INTERNATIONAL UNIVERSITY}

Miami, Florida

FEAR AND U.S. FOREIGN POLICY

DURING THE TRUMAN ADMINISTRATION,

$1945-1952$

A thesis submitted in partial fulfillment of the requirements for the degree of

MASTER OF ARTS

in

HISTORY

by

Jessica Rose Barrella 
To: Dean Arthur W. Herriott

College of Arts and Sciences

This thesis, written by Jessica Rose Barrella, and entitled Fear and U.S. Foreign Policy During the Truman Administration, 1945-1952, having been approved in respect to style and intellectual content, is referred to you for judgment.

We have read this thesis and recommend that it be approved.

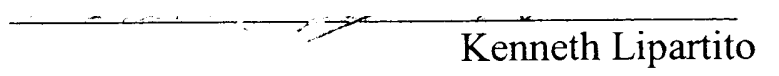

William O. Walker III, Major Professor

Date of Defense: July 18, 2002

The thesis of Jessica Rose Barrella is approved.

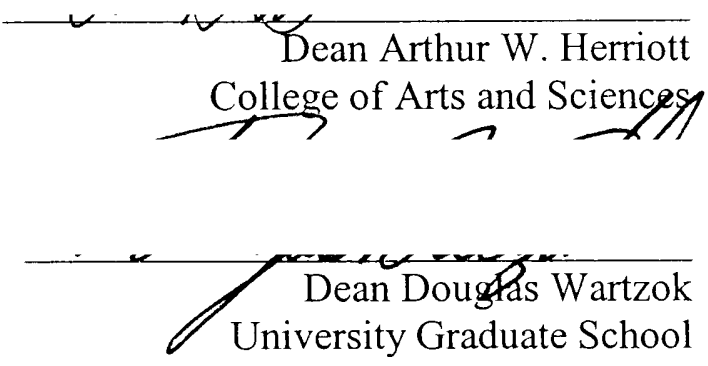

Florida International University, 2002 
(C) Copyright 2002 by Jessica Rose Barrella

All rights reserved. 


\section{ACKNOWLEDGMENTS}

I would like to thank my family, friends and the History department for all of their support and encouragement. 


\title{
ABSTRACT OF THESIS
}

\author{
FEAR AND U.S. FOREIGN POLICY \\ DURING THE TRUMAN ADMINISTRATION,
}

$1945-1952$

by

Jessica Rose Barrella

Florida International University, 2002

Miami, Florida

Professor William O. Walker III, Major Professor

The purpose of this study was to investigate how the Truman administration used fear to generate popular support for its Cold War foreign policies. Three issues were examined through the use of published government documents, personal memoirs, and weekly periodicals to assess the responses of the American public: the enactment of universal military training (UMT), the Soviet detonation of an atomic device, and the Truman administration's decision to build the hydrogen bomb. This study shows that the changing attitudes in the Truman administration toward the Soviet Union occurred in a climate of fear. Through press releases and by exerting influence on the media, the administration attempted to control the information the public received. Through the use of propaganda, the Truman administration pursued the implementation of UMT, generated fear of the Soviet Union after its detonation of the atomic bomb, and gained relative public support for the decision to build the hydrogen bomb. 


\section{TABLE OF CONTENTS}

\section{CHAPTER}

PAGE

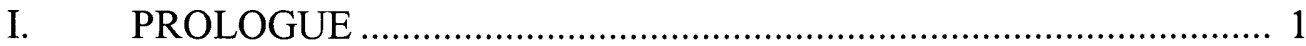

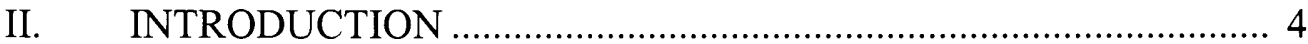

III. UNIVERSAL MILITARY TRAINING ....................................... 16

IV. THE SOVIET ATOMIC BOMB …............................................ 46

V. TRUMAN'S HYDROGEN BOMB DECISION ............................. 70

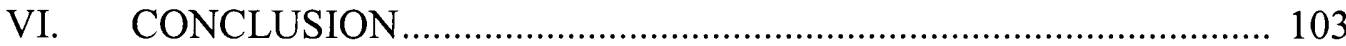

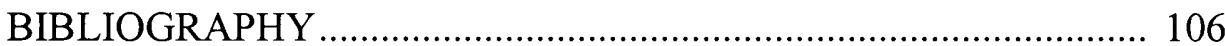




\section{Prologue}

About ten miles from the detonation site, observers crouched on the ground wearing protective gear, anxiously awaiting the first testing of a nuclear bomb. On July 16, 1949 at 5:30 Mountain Standard Time, just before sunrise, the first explosion of a nuclear device occurred. Project Trinity was long awaited by the few government officials that knew about it and the scientists that worked on it. ${ }^{1}$ Having been dropped from a tower as little as one hundred feet high in Alamogordo, New Mexico, the test was considered a success. No one quite knew what to expect, and some did not expect the bomb to detonate at all. But those that were present were eagerly waiting to see the effects of the bomb and its results. ${ }^{2}$

The effects did not disappoint. The initial blast created a tremendous light. Physicist Enrico Fermi was one of the observers and wrote "My first impression of the explosion was the very intense flash of light, and a sensation of heat on the parts of my body that were exposed. Although I did not look directly towards the object, I had the impression that suddenly the countryside became brighter then in full daylight." ${ }^{3}$ Soon after the initial blast, Kenneth Greisen noted, "the ground shock and sound reached us almost simultaneously. The noise lasted for a long time, echoing back and forth from the

\footnotetext{
${ }^{1}$ For a complete study on the Trinity Project see: Ferenc Morton Szasz, The Day the Sun Rose Twice: The Story of the Trinity Site Nuclear Explosion July 16, 1945 (Albuquerque, New Mexico, 1984).

${ }^{2}$ U.S. Nuclear Testing From Project Trinity to the Plowshare Program. Internet Site: http://www.enviroweb.org/issues/nuketesting/atmosphr/ustests.htm

${ }^{3}$ Trinity Test, July 16, 1945, Eyewitness Accounts-Enrico Fermi. Internet Site: http://www.dannen.com/decision/fermi.html
} 
hills."4 Afterward, everyone cheered. Edwin M. McMillan, another spectator, wrote that "the whole spectacle was so tremendous and one might almost say fantastic that the immediate reaction of the watchers was one of awe rather than excitement...I am sure that all who witnessed this test went away with a profound feeling that they had seen one of the great events of history."

The successful detonation of the first atomic device in the history of the world reached President Harry S. Truman the same morning of the explosion while he was at the Potsdam Conference where he was to discuss postwar planning with Winston Churchill and Josef Stalin. Secretary of War Henry L. Stimson delivered the news to the President, which he received with great excitement. He "realized that the test not only met the most optimistic expectations of the scientists but that the United states had in its possession an explosive force of unparalleled power." ${ }^{\text {Th }}$ This unparalleled power could also be used as a diplomatic weapon against the Soviets. Winston Churchill noticed an immediate change in the President's confidence at Potsdam, and noted, "After having read this report, he was a changed man. He told the Russians just where they got on and off and generally bossed the whole meeting."7 Stimson noted in his diary that he was amazed with the "differences in psychology which now exists since the successful test.", It was the President's intent to use the most powerful weapon of mass destruction not

\footnotetext{
${ }^{4}$ Trinity Test, July 16, 1945, Eyewitness Accounts-Kenneth Greisen. Internet Site: http://www.dannen.com/decision/greisen.html

${ }^{5}$ Trinity Test, July 16, 1945, Eyewitness Accounts-Edwin M. McMillan. Internet Site: http://www.dannen.com/decision/momillan.html

${ }^{6}$ Harry S. Truman, Year of Decision, vol. 1 of Memoirs by Harry S. Truman (Garden City, New Jersey, 1955), p. 415.

${ }^{7}$ Lawrence S. Whittner, One World or None: A History of the World Nuclear Disarmament Movement Through 1953, vol. 1 of The Struggle Against the Bomb (Stanford, California, 1993), p. 34.

${ }^{8}$ Melvyn P. Leffler, A Preponderance of Power: National Security, the Truman Administration, and the Cold War (Stanford, California, 1992), p. 38.
} 
only to win the war against the Japanese, but also to boost the international power of the United States after the war. Truman and Churchill decided Stalin should be informed of the news. Truman wrote in his memoirs, "On July 24 I casually mentioned to Stalin that we had a new weapon of unusually destructive force." What the President failed to mention was that the destructive force was an atomic weapon, a weapon that would change the course of history, help to ignite the Cold War, and instill a sense of ubiquitous fear into every American for generations to come.

\footnotetext{
${ }^{9}$ Truman, Year of Decision, 416.
} 


\section{Introduction}

On August 6, 1945, a B-29, the Enola Gay, dropped an atomic bomb over the Japanese city of Hiroshima. "Little Boy" exploded 1900 feet from the ground with the equivalent of about twelve and one-half thousand tons of TNT. The effects of the bomb were superior to Trinity. President Truman was immediately informed and was elated. ${ }^{1}$ While describing the importance and the secrecy of the bomb project to the American public, the White House press release declared both the obstinacy of the Japanese and the new omnipotence of the United States through the strength of the atomic bomb.

Truman said that the atomic bomb was a

[h] arnessing of the basic powers of the universe. The force from which the sun draws its power has been loosed against those that brought war to the Far East. We are more prepared to obliterate more rapidly and completely every productive enterprise the Japanese have above ground in any city. We shall destroy their docks, their factories and their communications. Let there be no mistake; we shall completely destroy Japan's power to make war. ${ }^{2}$

When the Japanese still refused to surrender unconditionally, "Fat Man" was dropped on

Nagasaki. Although the impact was less severe than that of Little Boy, the second atomic bomb pushed Japan to an unconditional surrender that ended the war. ${ }^{3}$

Almost immediately, Americans wanted more specific information about the effects of the bombing on the two Japanese cities. But this information was not forthcoming. Instead, the press reported on the enormous power of atomic energy and its implications

\footnotetext{
${ }^{1}$ Harry S. Truman, Year of Decisions, vol.1 of Memoirs by Harry S. Truman (Garden City, 1955), p. 422.

${ }^{2}$ Statement By The President of the United States, August 6, 1945. Internet Site: http://www.enviroweb.org/issues/nuketesting/hiroshima/truman1.htm

${ }^{3}$ Richard Rhodes, The Making of the Atomic Bomb (New York, 1986), p. 740.
} 
for the future. By the beginning of September, there was speculation about how the armed forces of the United States were going to incorporate this new super weapon into their arsenals for future military engagement. The press was asking how the U.S. government was also going to adapt this weapon to the cause of world peace. U.S. News and World Report questioned whether the atomic bomb could be used for peaceful means, but was able to give readers a clear idea of the awesome capabilities of the bomb by describing it as "solely a weapon of war ... [that] can evolutionize, even revolutionize, offensive and defensive combat. It may become the most influential single factor in world affairs." ${ }^{4}$ The magazine also emphasized that the atomic bomb could obliterate everything within a one and one-half mile radius and that it had the ability to cause "metals to evaporate and human blood disintegrate." Soon many news magazines were inquiring into the destructive capabilities of this new weapon. While the experts in the American government were saying that the effects of radiation caused by the blast would only last a few days, the Japanese disclosed that "they linger indefinitely." Thus, while the American public was not informed of the direct damage caused by the atomic bomb, periodicals were beginning to inform Americans of the awesome power of the bomb. The American public understandably began to fear what the future might hold.

Although the atomic bomb had ended one war, it began the process of preparedness for the next conflict for the United States. President Truman wrote in his memoirs that it was the intention by the U.S. government to hold on to the secret of atomic energy as long as possible. From the beginning, the A-bomb was a weapon that might be used for

\footnotetext{
4 "Atomic Force in War and Peace: Sequel to Bombing of Japan," U.S. News and World Report, September 7, 1945, pp. 28-29.

${ }^{5}$ Ibid.

${ }^{6}$ Ibid.
} 
diplomatic purposes because of the fear it induced, and the authority it commanded. The atomic bomb was not only able to devastate entire cities and possibly destroy civilization itself, it was also the key, Truman believed, to preponderant world power for the United States. It was this new role for which the United States needed to prepare.

After the war, the Truman administration encouraged fear within the American public toward the Soviet Union and its ostensible ability to wage war against the United States. This fear was largely induced by the administration to aid in generating support for its foreign policies. Russia and its communist ideology had long induced suspicion within the American government. Only the threat of a common enemy during World War II had brought the two nations together. Although the relationship treaded a fine line during the war, it was after the death of President Franklin D. Roosevelt on April 12, 1945 , that the growing strain in the relationship between the two countries became most apparent and most critical. Harry S. Truman's anti-Soviet inclinations antedated his becoming president and as president, he directed foreign policy convinced that "[f]orce was the only thing that the Russians [understood].",

In the eyes of the new president, it was crucial that atomic energy be controlled within the United States by the government and internationally by the United Nations Organization. Such broad control was essential because it would monitor scientific and technological advancements in weaponry on a global scale. But most importantly, the guidelines for international atomic control would be set forth by the American

\footnotetext{
${ }^{7}$ Truman, Year of Decisions, 412. John Lewis Gaddis quotes Senator Truman as saying, "If we see that Germany is winning the war we ought to help Russia, and if Russia is winning, we ought to help Germany and in that way let them kill as many as possible." John Lewis Gaddis, Strategies of Containment: A Critical Appraisal of Postwar American National Security Policy (New York, 1982), p. 4.
} 
government. Thus, the United States would have first-hand access to atomic developments by potential enemy nations, such as the Soviet Union; the U.S. government had no intention of sharing the secret of the atomic bomb, especially with the Soviets who were quickly becoming the new postwar enemy of the United States.

The American concern with the Soviet Union became apparent soon after the war. U.S. News and World Report wrote of the unease of the government that the Russians would soon overtake the United States in science if something were not done. ${ }^{8}$ Bitter rivalry would replace prior cooperation and "competition for spheres of influence would intensify.... Gradually it is feared, all the nations would line up in one or another of the two armed camps, with U.S.-Britain leading one and Russia the other."9 It would now be the United States against U.S.S.R. in the international arena.

The inconsistent actions of the Soviet Union during the early years of the Cold War reinforced the suspicious feelings of policy makers in the United States. President Truman made no attempt to hide his contempt for the Soviets and their ideology. And as mentioned previously, the atomic bomb re-enforced the Truman administration's confidence in its global role. U.S. Policy makers felt the need for the centralization of government power because it would help to control and redirect anti-Soviet decisionmaking. The political body that advised President Truman, which would be formally reconstituted in July 1947 as the National Security Council (NSC), was adamantly opposed to the Soviet Union and worried about its active role in international affairs. These men feared the Soviet Union because they deemed it a direct threat to the security

\footnotetext{
8 "Government's Role in Science: A Key to World Leadership," U.S. News and World Report, October 19, 1945, pp. 30-31.

9 "Proffering the Atomic Secret: Security for World as Price," U.S. News and World Report, November 23, 1945, pp. 11-13.
} 
of the United States. It was this fear that would govern the early Cold War policy of the United States, as well as be used to intensify the already existent fears within the public.

The psychology of decision making in the early Cold War showed how policy makers reacted in an uncertain environment. As Irving L. Janis and Leon Mann wrote in their classic study, Decision Making, "[T]he fact remains that human beings . . . seldom can approximate a state of detached affectlessness when making decisions that implicate their own vital interests or those of their organization or nation."10 The Truman administration had a "cognitive consistency," in the sense that it believed that other countries and their governments should be run in a way compatible with the beliefs and values of the United States. As explained in Between War and Peace by Richard Ned Lebow, "[W]e tend to believe that people we like act in ways we approve of, have values similar to ours, and oppose people and institutions that we dislike. People we dislike, we expect to act in ways repugnant to us, have values totally dissimilar then ours, and to support people and institutions that we disapprove of." 11 Placed in the context of American foreign policy, the search for cognitive consistency by policy makers in the U.S. government reinforced their pre-existing beliefs and helped justify future involvement in foreign affairs. As stated in 1944 by Assistant Secretary of State Dean G. Acheson, "We are willing to help people who believe the way we do, to continue to live the way they want to live." ${ }^{, 2}$ This revealing policy statement would in time provide the

\footnotetext{
${ }^{10}$ Irving L. Janis and Leon Mann. Decision Making: A Psychological Analysis of Conflict, Choice, and Commitment (New York, 1977), p. 45.

${ }^{11}$ Richard Ned Lebow, Between Peace and War: The Nature of International Crisis (Baltimore and London, 1984), p. 102.

${ }^{12}$ Acheson quoted in Lloyd C. Gardner, Architects of Illusion: Men and Ideas in American Foreign Policy, 1941-1949 (Chicago, 1970), p. 205.
} 
rationalization that in effect allowed fear and the willingness to use power to govern the foreign and domestic policies of the United States throughout the early years of the Cold War.

At that time, it was essential for the United States to maintain its newly acquired status as a superpower. The Truman administration was overtly assertive from the beginning about the importance of an atomic monopoly and its implication for American power and world politics. This thesis will focus on three important issues confronting the Truman administration, each of which drastically affected the American public and escalated tensions between the United States and the Soviet Union. The Truman administration used fear, sometimes intentionally, to generate popular support for its Cold War foreign policies. The three issues will be examined through the use of memoirs, published government documents, and weekly periodicals of the time to assess the fears of writers as well as readers. The fear that was exhibited and propagated by the Truman administration - by selective White House press releases and loyalty laws - in the early years of the Cold War significantly contributed to the ability of the U.S. government to take an aggressive approach toward the Soviet Union.

The attempt to implement universal military training for all young men after World War II will be the first issue examined. The importance of this objective, according to the president, was to keep the United States in a state of preparedness in case of a future war. The likelihood of war was propagated through the press as the administration stressed the deteriorating relations with the Soviet Union. Because of a fear of the unknown, more than three-quarters of Americans supported the enactment of UMT. 
Although Congress eventually did not accept the idea of a garrison state, the proposal held the floor almost the full length of Truman's Presidency. ${ }^{13}$

The second issue to be addressed concerns the detonation of an atomic bomb by the Soviet Union. Because of the suspicions of the American government about Soviet intentions, the loss of the atomic monopoly by the United States was arguably a devastating blow to its national security. Although scientists had predicted that the United States could not long possess atomic secrets, the Truman administration was not prepared for the Russian bomb. According to intelligence experts, the Russians were not expected to detonate any atomic device before $1952 .{ }^{14}$ Soviet atomic power enhanced the fear that was already instilled in the American public. With the help of weekly periodicals, which frequently published articles about the military use of atomic power, Americans began to fear the probability of a third world war. Most importantly, Americans wanted to know if the United States would be able to defend itself against a nuclear attack.

The last issue to be addressed is that of the Truman administration's decision to build a hydrogen bomb. This decision was in direct reaction to the Soviet atomic bomb. Scientists had discussed the idea of the hydrogen bomb for several years because it was logically the next stage of the atomic project. The presidential decision to begin the hydrogen bomb was, however, a direct consequence of the successful Soviet detonation of the atomic bomb and its evident effect on American security. Now Americans were questioning the ability of civilization itself to survive.

\footnotetext{
${ }^{13}$ For a thorough examination of the United States as a garrison state see Aaron L. Friedberg, In the Shadow of the Garrison State: America's Anti-Statism and its Grand Strategy (Princeton, 2000).

${ }^{14}$ Harry S. Truman, Years of Trial and Hope, vol. 2 of Memoirs by Harry S. Truman (Garden City, 1956), p. 306.
} 
The primary purpose of this thesis is to study how the American public reacted to these monumental issues during the early years of the Cold War. A secondary purpose is to assess the lengths to which the Truman administration went in propagating its foreign policy through the use of the press. Doing so makes the matter of fear an important consideration for analytical purposes. Both the positive and the negative responses by the public to each of these three issues will be examined.

There are two facets to the research problem. The first aspect is the notion that fear could be utilized as discourse in the response of the American public to the Truman administration's foreign policy. Discourse, according to authors Timothy Kelly and Joseph Kelly, is an attitude or emotion so fundamental to a particular culture that it is no longer obvious. "To [the majority of the population]," they write, "it is simply the way things are-an unquestionable act of nature."15 Universal military training and the decision of the U.S. government to build the hydrogen bomb were serious matters that the American public faced. I argue that fear is seen in the acceptance or questioning by Americans the wisdom of these policies of the Truman administration.

The second facet of the research problem is the usage of propaganda by the U.S. government and the press. Through controlled press releases, loyalty laws, and by exerting influence on the print media, Truman and his advisors were able to regulate the information that the American public received. Although this information was filtered, the press was able to interpret the fear it contained and in so doing managed to sensationalize it. Propaganda was used as a tool by the government of United States to

\footnotetext{
${ }^{15}$ Timothy Kelly and Joseph Kelly, "American Catholics and the Discourse of Fear," in Peter Stearns and Jan Lewis, eds. An Emotional History of the United States (New York and London, 1998), pp. 259-279.
} 
achieve its military and budgetary needs and at other times to manipulate the public indirectly via the press. A perfect example of this propaganda effort is in the reaction to the Soviet detonation of the atomic bomb. We shall see how the U.S. government's use of propaganda instilled considerable fear in the American people.

The role of fear is an important consideration because a discourse of fear is only possible within an existent climate of fear. Concerns about the U.S.S.R. within the Truman administration during its early months in office reveal the presence of this climate of fear. In their memoirs Secretary of Defense James Forrestal, Ambassador to the Soviet Union Averell Harriman, George Kennan, Charles Bohlen, and Harry S. Truman each noted their fear of Soviet power and its growing influence in world affairs. Forrestal wrote of the "universal fear of the Russian colossus" because of its size and "locust-like effects of their occupation." Harriman worried that "Stalin's insistence upon a belt of weak, easily dominated neighboring states" would not be limited to Eastern Europe, ${ }^{17}$ and Bohlen noted that if it were not for the Marshall Plan, the Soviet Union would have taken over most of Western Europe. ${ }^{18}$ Bohlen also asserted that it was the Stalin's aim to control all communist led countries. ${ }^{19}$ Both Harriman and Bohlen informed the president of their fears about the Soviets. In his now famous Long Telegram, Kennan successfully alerted the American government of Russian intentions to separate the globe into two spheres, "between which there was no possibility of

\footnotetext{
${ }^{16}$ Millis, Walter, ed., The Forrestal Diaries (New York, 1951), p. 106.

${ }^{17}$ W. Averell Harriman and Elie Abel, Special Envoy to Churchill and Stalin, 1941-1946 (New York, 1975), p. 449.

${ }^{18}$ Charles E. Bohlen, Witness to History, 1929-1969 (New York, 1973), p. 268.

${ }^{19}$ Ibid., pp. 290-291.
} 
peaceful coexistence."20 The Truman administration was enveloped in a climate of fear as early as 1946, when the president declared at a staff meeting that "[the United States is] going to war with Russia.",21

Scholars such as the leading post-revisionists Melvin Leffler, Michael J. Hogan, and Arnold A. Offner have explored the foreign policies of the Truman administration from several angles. ${ }^{22}$ All three conclude that the Truman administration did the best it could given the new international power of the United States and the circumstances of the postwar period. However, Offner's views of President Truman and his administration are quite critical: “Truman . . . narrowed Americans' perceptions of the world political environment and the channels for policy choices and created a rigid framework in which the United States waged long-term, extremely costly global Cold War." ${ }^{23}$ Historian John Lewis Gaddis has also put the Truman administration in the spotlight. Gaddis concludes that the postwar security of the United States was possible only through the containment of the Soviet Union. The research of these notable historians of the Cold War focuses on the Truman administration's foreign policies and the impact that these policies had on international affairs.

\footnotetext{
${ }^{20}$ George Kennan, Memoirs, 1925-1950 (Boston: 1967), pp. 292-295; quote from Harriman, Special Envoy, p. 547. "Forrestal considered the Kennan telegram so important that he had it mimeographed and distributed to all members of the Truman Cabinet in anyway concerned with foreign or military affairs. In a matter of days, accordingly, the official Washington attitude [toward the Soviet Union] hardened perceptively," Harriman, Special Envoy, p. 548.

${ }^{21}$ Robert H. Ferrell, Truman in the White House: The Diary of Eben A. Ayers (Columbia, 1991), p.135.

${ }^{22}$ Melvyn P. Leffler, A Preponderance of Power: National Security, the Truman Administration, and the Cold War (Stanford, 1992); Michael J. Hogan, A Cross of Iron: Harry S. Truman and the Origins of the National Security State, 1945-1954 (New York, 1998); Arnold A. Offner, Another Such Victory: President Truman and the Cold War, 1945-1953 (Stanford, 2002)

${ }^{23}$ Arnold A. Offner, Another Such Victory, p. xii.
} 
Two other historians are worth noting for their unconventional approach to the study of the early years of the Cold War. In Homeward Bound, ${ }^{24}$ Elaine Tyler May examines the domestic scene of the Cold War. She focuses on the impact of foreign policy and the policy of containment during the Cold War and its effects on the American family. Fear has a role in May's study, but it is not central to her analysis. The late Frank Kofsky, in Harry S. Truman and the War Scare of $1948,{ }^{25}$ places great emphasis upon fear in the making of U.S. foreign policy. His belief was that the Truman administration purposely and needlessly created fear within the American public to further its foreign policy agenda.

My contribution to the scholarship on the early years of the Cold War is the study of fear induced by the Truman administration on the American people as a whole through its foreign policy choices and administrative decisions. I will ague that fear, as an emotion, was central in the making of foreign policy during the early years of the Cold War. Currently, the historian most perceptively investigating the role of emotions in foreign relations is Frank Costigliola. ${ }^{26}$ It is clear, by the examination of periodical literature, that the Truman administration was able to induce fear into the people of the United States as a consequence of its view of the international scene and its policy decisions. This fear is clearly seen in the reactions of journalists and what they chose to report and when, as well as in the effect their reports had on the public as seen in

\footnotetext{
${ }^{24}$ Elaine Tyler May, Homeward Bound: American Families in the Cold War Era, rev. ed. (New York, 1999).

${ }^{25}$ Frank Kofsky, Harry S. Truman and the War Scare of 1948: A Successful Campaign to Deceive the Nation (New York, 1993).

${ }^{26}$ Frank Costigliola, “ 'Unceasing Pressure for Penetration': Gander, Pathology, and Emotion in George Kennan's Formation of the Cold War," Journal of American History 83 (March 1997): 130939.
} 
responses to these writings. Unlike Kofsky, I argue that the fears experienced by U.S. officials may well have been justified. The key issues for me are how and why their fears were exacerbated.

It is also clear that, through the use of propaganda-the control of information, the Truman administration was able to persuade the American public to accept a new international role for the United States in the early postwar years. After World War II, Americans were slowly beginning to accept that they could no longer escape the newly emerging world environment. It is my intention to show that the Truman administration was able to pursue the implementation of universal military training by its propaganda of the danger of the Soviet Union in its foreign policy agenda. The administration was also able to induce fear within the American public with the announcement of the Soviet detonation of the atomic bomb. And it was through this fear that Truman's decision to build the hydrogen bomb was generally accepted by the American public. 


\section{Chapter 1}

\section{Universal Military Training}

Almost immediately after Harry S. Truman became President of the United States, diplomatic relations with the Soviet Union took an abrupt turn. On April 23, 1945, President Truman called a private meeting with his top diplomatic and military advisors. The meeting was to discuss the attitudes and actions of the Soviet Ambassador Vyacheslav Molotov concerning the Polish question. The Russians had set up a "puppet government" in Lublin, Poland, which did not meet the criteria of the U.S. government. ${ }^{1}$ Because the Lublin government was not a true representative of the Polish people and the government not a democracy, its existence was proof to the White House that the Russians were not abiding the Yalta agreements of February 1945. Therefore, this action proved that Soviet leaders were unreliable and untrustworthy, but more importantly it indicated that they were eager to dominate Eastern Europe. In short, the Soviet Union seemed to constitute a threat to emerging U.S. global interests.

After asking those present of their views on the Russian problem, President Truman declared that American agreements with the Russians have been "a one-way street and that he would not continue [in that manner]; it was now or never," and the Russians "could go to hell" if they would not cooperate. President Truman had long felt animosity toward the Soviets and their political system. Secretary of the Navy James

\footnotetext{
${ }^{1}$ For a thorough first-hand examination on the Soviet instillation of the Lublin government in Poland see W. Averell Harriman and Elie Abel, Special Envoy to Churchill and Stalin, 1941-1946 (New York, 1975).
} 
Forrestal said that a "showdown" with the Russians would be better now than later.

The men surrounding the president during his first days in office enforced their view that the United States needed to stand firm with the Soviet Union. It was only Secretary of War Henry L. Stimson who suggested otherwise. ${ }^{3}$ Soon after, at the United Nations meeting in San Francisco, American Ambassador to the Soviet Union W. Averell Harriman "advanced the view that the goals of the Soviet Union and the United States were so opposed that any possibility of future cooperation was not realistic." ${ }^{4}$

On April 23, after President Truman conferred with his advisors, Molotov came in to see him. Without protocol, Truman went straight to the point. The president said that he regretted that there was no progress solving the Polish problem and that the "United States was determined ... to go ahead with plans for the world organization, no matter what difficulties or differences might arise with regard to other matters." ${ }^{\circ}$ Furthermore, Truman expressed his doubt as to the "unity of purpose" of the Soviet Union in the postwar world. When Molotov attempted to defend the actions of the Soviet Union, Truman "briskly and firmly said he was not interested in propaganda." Truman then told

${ }^{2}$ Walter Millis, ed. The Forrestal Diaries, (New York, 1951), pp. 50-51. Forrestal's paranoia about Communism is well known to historians of the Cold War. Lloyd C. Gardner wrote: "As parody on parody, Forrestal's demeanor resembled Ichabod Crane's terrified flight in Sleepy Hollow-were it not for the fact that these views soon were not considered unusual at all." Gardner also noted during the war Forrestal believed that "world capitalism was under siege," and he kept "large files on individuals, organizations and publications he suspected of being under communist influence." Architects of Illusions: Men and Ideas in American Foreign Policy, 1941-1949 (Chicago, 1970), pp. 174, 271.

${ }^{3}$ John Lewis Gaddis, The United States and the Origins of the Cold War (New York and London, 1972), p. 202.

${ }^{4}$ Charles E Bohlen, Witness to History, 1929-1969 (New York, 1973), p. 215; W. Averell Harriman, America and Russia in a Changing World: A Half Century of Personal Observation (Garden City, 1971), pp. 38-44; Charles E. Bohlen was the Russian interpreter for President Truman.

${ }^{5}$ Harry S. Truman, Year of Decision vol. 1 of Memoirs By Harry S. Truman (Garden City, 1955), p. 80. 
Molotov that he was dismissed. ${ }^{6}$ Later, the president doubted himself and wondered if he did the right thing. ${ }^{7}$

Although the Second World War had not yet been won, Truman and his advisors were already thinking of postwar circumstances. They were concerned with the effects of demobilization and American security. The advancement in military technology foreshadowed the importance of a continual state of preparedness. Like those that surrounded him, President Truman believed in instituting a universal military training (UMT) program. The enactment of UMT, Truman felt, would enable the country to prepare for the unknown, and help dissipate public fears. Because the U.S. government was fearful of a future attack, and was skeptical of relations with the Soviet Union, universal military training was put forth as the remedy. Throughout Truman's presidency, it was believed that UMT would not only give the United States the security it was looking for, but it would also deter the Soviets in their "program of expansion.", The attempt of the Truman administration to enact UMT and the climate of fear surrounding the accompanying debate will be the subject of this chapter.

The British view of the Soviets in April 1945 did not differ from that in the White House, though the element of fear was not as pronounced. British Prime Minister Winston Churchill had been sending appeals to Truman "for American military occupation of as much territory as possible [after the European War] to obtain the

\footnotetext{
${ }^{6}$ Bohlen, Witness to History, p. 213; For more information on Molotov's meeting with Truman also see: Harry S. Truman, Year of Decisions, pp. 80-82; Harriman, Special Envoy, pp. 451-454.

${ }^{7}$ Arnold A. Offner, Another Such Victory: President Truman and the Cold War, 1945-1953 (Stanford, 2002), p. 34.

${ }^{8}$ Truman, Year of Decision, p. 512.
} 
strongest negotiating position with the Soviets." Churchill had long despised communism and on May 12, 1945, he sent Truman another message, speaking for the first time of the "iron curtain" within Europe. Arnold A. Offner recently wrote that Churchill's anticommunism dated back to the Russian civil war of 1918, when he favored Western intervention. In May 1940, Churchill "held to his belief that harmony was impossible between 'Bolshevism and present civilization.",10

Relations between the Soviet Union and the United States were jeopardized even further, following the Truman-Molotov meeting, when only three days after the announcement of the surrender of Germany, Truman signed an order without reading it that restricted lend-lease to the Soviet Union. This act created uproar among the Soviets and contributed to their mounting mistrust of the United States. ${ }^{11}$

National security and a state of preparedness became a critical concern for Americans toward the end of the war. It was clear that should another war erupt, the United States could no longer rely on other countries to carry the initial burden of war. Because the United States had become the world's super power, it was feared that it had also become the primary target of future aggressors. ${ }^{12}$ The geography of the United States would no longer provide effective protection. The development of atomic

\footnotetext{
${ }^{9}$ Bohlen, Witness to History, p. 216.

${ }^{10}$ Offner, Another Such Victory, pp. 25-26.

${ }^{11}$ Robert H. Ferrell, Harry S. Truman: A Life (Columbia and London, 1994), p. 199; for a first-hand account see: Harry S. Truman, Year of Decisions, p. 228; for a thorough examination see: George C. Herring Jr., "Lend-Lease to Russia and the Origins of the Cold War, 1944-1945," Journal of American History 56 (June 1969): 93-114; Thomas G. Paterson, Soviet-American Confrontation: Postwar Reconstruction and the Origins of the Cold War, (Baltimore and London, 1973), pp. 43-46; ${ }^{12}$ Michael J. Hogan, A Cross of Iron: Harry S. Truman and the Origins of the National Security State, 1945-1954 (New York, 1998), p. 25.
} 
weapons, enhanced airpower, and the modern missiles developed by Germany made a sudden attack a possibility and emphasized the importance of continual preparedness.

At the same time, the strength of the Soviet Union also became a matter of much concern. Although Franklin D. Roosevelt and America's top military officials had tried to work toward a cooperative relationship with Russia, it was clear to Truman and his advisors that the objectives of the Soviet Union were not compatible to those of the United States. Both countries doubted the integrity of the other; both were also suspicious of one another largely because of their ideological differences. As Melvyn P. Leffler describes the American-Soviet relationship in The Specter of Communism: "From the beginning, there was an ideological clash."13 In U.S. News and World Report, Stalin and Molotov were compared to Hitler; and appeasement, the magazine concluded, had encouraged the onset of WWII. Therefore, the world must not appease the Soviets. The magazine stressed that "[u]ntil the flames of totalitarianism are extinguished around the world, there will be a danger of another world-wide conflagration.",14

Just as important was the growth in communist popularity throughout the world, which would pose great dilemmas for U.S. leaders. As Leffler observes, "Policymakers in Washington assumed that wherever and however Communist gained power, they would pursue policies that directly or indirectly served the purposes of the Soviet

\footnotetext{
${ }^{13}$ Melvyn P. Leffler, The Specter of Communism: The United States and the Origins of the Cold War, 1917-1953 (New York, 1994), p. 3.

${ }^{14}$ David Lawrence, “The Road to World War III?" U.S. News and World Report, June 7, 1946, pp. 28-29; also see: Les K. Adler and Thomas G. Paterson, "Red Fascism: The Merger of Nazi Germany and Soviet Russia in the American Image of Totalitarianism, 1930's-1950's," American Historical Review 75 (April 1970), pp.1046-1064.
} 
government." ${ }^{, 15}$ In the October 10, 1945 issue of U.S. News and World Report, there was

a two-page statement opposed to Communism, entitled "The Hearst Newspapers Have Always Led in Exposing and Opposing COMMUNISM."16 Because of the contradictory actions of the Soviet government, its intent was not always clear to the White House. The Truman administration was guided by prudence in order to, in Leffler's words, “dilute Soviet predominance in Eastern Europe and deter the expansion of Soviet Russia beyond it."17 Another scholar has captured the urgency of the moment by noting that it was feared the Soviet Union would "quickly extend their control across all of Eurasia, filling the power vacuums in Western Europe and Northeast Asia and gaining control, in the process, of vast human, natural, and industrial resources." ${ }^{\text {"18 }}$ U.S. News and World Report asked: Is the United States "On the Road to World War III?" Written by David Lawrence, the article concluded that because "totalitarianism menaces peace," it was Moscow that must answer the question, not Washington. ${ }^{19}$

Before the end of the war in the Pacific with the dropping of an atomic bomb, top officials in the White House were already discussing postwar American security. There was a concern for preparedness after the war: it was foreseen that the future enemy of the United States would be Russia. Forrestal noted on April 20, 1945, that Harriman had

\footnotetext{
${ }^{15}$ Melvyn P. Leffler, A Preponderance of Power: National Security, The Truman Administration, and the Cold War (Stanford, 1992), p. 7.

16 "The Hearst Newspapers Have Always Led In Exposing and Opposing COMMUNISM," U.S. News and World Report, October 10, 1945, pp. 46-47. There were 17 different daily newspapers in the Hearst chain in 1940, and in the course of his career, he owned up to 42 dailies. For more information on the power of the newspaper syndicate see: James Aronson, The Press and the Cold War (Indianapolis, 1970), pp. 13-16.

${ }^{17}$ Leffler, A Preponderance of Power, p. 36.

${ }^{18}$ Aaron L. Friedberg, In the Shadow of the Garrison State: America's Anti-Statism and Its Cold War Grand Strategy (Princeton, 2000), pp. 38-39.

${ }^{19}$ David Lawrence, "The Road to World War III?" U.S. News and World Report, June 7, 1946, pp. 28-29.
} 
said that communism was not dead and that the United States "might well have to face an ideological warfare just as vigorous and dangerous as Fascism or Nazism." ${ }^{20}$ Future scientific developments were in question in an article in Foreign Affairs. The atomic bomb had not been successfully tested, let alone publicly disclosed; yet George Fielding Eliot wrote:

The stupendous scientific developments of the last hundred years have now been brought to the point where it is entirely conceivable that an anemic professor in an underground chamber may reach over and touch a button and kill a thousand men a thousand miles away. . . . Can we permit any more secrets if machines secretly produced threaten to destroy us all? ${ }^{21}$

While the Truman administration was gathering together as much strength and security as it could from Latin and South America through the ratification of Article 51 of the United Nations Charter, the administration was also focused on the containmentas it soon came to be called-of Russia and the growing communist presence in neighboring countries. President Truman received two reports emphasizing the Soviet intent to dominate Eastern Europe through expansion, while also stressing the importance of American military strength and the importance of American "national security."22 The growing suspicions and fears of possible future confrontations between the allies helped to initiate universal military training discourse among American policymakers.

President Truman had long believed in the necessity of a citizen soldier. In his memoirs, he wrote, "I have always believed that military preparedness is necessary to

\footnotetext{
${ }^{20}$ Millis, The Forrestal Diaries, p. 47.

${ }^{21}$ George Fielding Eliot, "Science and Foreign Policy," Foreign Affairs: An American Quarterly 23 (April 1945): 378-387.

${ }^{22}$ Offner, Another Such Victory, p. 41.
} 
national security."23 Truman traced his argument for the use of the citizen soldier back to the Republic of George Washington. Although conscription had been used in the past in form of the draft, Truman saw the need for conscription in peacetime of all young men upon their eighteenth birthday. Truman's argument for the plan focused not only on the security it would provide, but also on the positive influence it would have on the men during training. Part of his proposal emphasized its capacity to develop the skills of ordinary life, such as literacy, responsibility, physical standards, as well as "to foster the moral and spiritual welfare of our young people." ${ }^{24}$ To reinforce his proposal, Truman cited the 34 percent of young men were unfit for the draft because of physical defects. But most importantly, Truman's recommendation of universal military training to Congress was to "have ... a pool of basically trained men which would [make] the Soviets hesitate in their program of expansion in certain strategic parts of the world." 25

The introduction of UMT was placed within the emerging national security ideology and focused on political values, military strategy and weaponry as well as technological might. Placed within this context, Michael J. Hogan writes, "Truman and his allies articulated the new ideology of national security, with its conviction that total war compelled the integration of civilian and military resources into a program of constant preparedness."26 As Aaron L. Friedberg has noted, because of what had happened during the Second World War, "the notion that a hostile power or coalition might be able to achieve rapid conquests, accumulate resources, deprive the United States of

\footnotetext{
${ }^{23}$ Truman, Year of Decision, p. 510.

${ }^{24}$ Ibid., p. 511.

${ }^{25}$ Ibid., p. 512.

${ }^{26}$ Hogan, p. 120.
} 
markets and allies, isolate it diplomatically and geographically, and perhaps eventually bring it to its knees did not seem in the least far-fetched." ${ }^{27}$ Communism, therefore, was not just seen as an ideological threat to the United States, but it was also seen as an economic threat. Americans were continually concerned about a resurgence of a depression similar to the one in the 1930s: Americans were fearful of the unknown. A communist take-over in Eastern Europe would limit American markets and thereby reduce the financial security of the United States. These fears were successfully communicated to the American public.

UMT offered one way to address these fears. According to The Public Opinion Quarterly's questions on compulsory military training, most American agreed with the need for UMT. Fifty-nine percent of those polled also believed that UMT would decrease the chances of a future war. ${ }^{28}$ This belief became a matter of contention in the early postwar period.

With the successful detonation of the atomic bomb on Japan, the importance of national security for the postwar era became more apparent. It was only a matter of time before another country would obtain nuclear power and the United States would no longer hold the atomic monopoly. According to Major Alexander P. de Seversky, special consultant to Secretary of War Robert P. Patterson, there was "atomic bomb hysteria," in the public at large. In his article written for The Reader's Digest, the atomic revolution had only just begun. de Seversky stated that although the "psychological value [of the bomb] was incalculable ... [and] the atom bomb fitted

\footnotetext{
${ }^{27}$ Friedberg, In the Shadow of the Garrison State, p. 39.

28 “The Quarter's Polls,” Public Opinion Quarterly 9 (Winter 1945-46): 521-523.
} 
propaganda purposes," it was but a "firecracker" compared to what would be developed in the near future. What de Seversky recommended was a cooling-off period from the speculation about atomic power. ${ }^{29}$

It was not until 1946 that the American public actually learned of the devastating effects of the atomic bomb. Time Magazine reprinted the first detailed account of the bombing of Hiroshima written by one of the survivors. ${ }^{30}$ The government tried to discredit rumors of the destructiveness of the atomic bomb by releasing "official facts on what the weapon could really do to civilian populations." The facts and pictures distributed by the government, however, only reinforced what had already been reported. ${ }^{31}$ Soon there was speculation about what the atomic bomb would do if dropped on cities within the United States. Articles in popular periodicals were no longer holding back details of the devastation the atomic bombs had caused in Japan or the devastation the atom would likely cause in the next world war. Scientists did not want the public to underestimate the power of this newly harvested nuclear energy.

Articles and editorials were continually stressing the possibility of another world war with the Soviet Union as the adversary. Graphic details and photographs of the victims of the first atomic weapons appeared in major magazines. An article in The Reader's Digest reinforced the idea of fear through the power of the atomic bomb with specific details. In this article, there was no hesitation to describe the power of the atom and what it could do to American cities in comparison to what the bomb had done on

\footnotetext{
${ }^{29}$ Major Alexander P. de Seversky, “Atomic Bomb Hysteria," The Reader's Digest 48 (January 1946): 121-126.

${ }^{30}$ Reverend John A. Siemes, "From Hiroshima: A Report and a Question," Time, February 11, 1946, pp. 26-27.

31 "Secrets of the Atomic Bomb Tests," U.S. News and World Report, May 9, 1947, pp. 24-25.
} 
Japan. ${ }^{32}$ Pictures and diagrams were given to readers to demonstrate and impress upon their minds how total war would directly affect them. Under a picture of the ruins of Hiroshima was the question: "Los Angeles, Chicago, Pittsburgh?"33 U.S. News and World Report mapped out the Soviet Union with the number of Soviet forces in each of its neighboring satellite countries. ${ }^{34}$ Look Magazine asked: "Can our civilization survive the atomic bomb?" Accompanying this article was a graphic drawing of a typical American town with a mushroom cloud in the background and people running in the foreground. $^{35}$ Time Magazine vividly diagramed the destructive capabilities of the atomic bomb within the boundaries of Washington D.C. ${ }^{36}$ The Nation put forth the question: "Can Man Survive?"37

Fear was being propagated through the press with speculation of atomic bombs being planted in American cities. Dr. Vannevar Bush, head of the Office of Scientific Research and Development, testified before the Senate Special Committee on Atomic Energy in an administration effort to "debunk" stories and rumors that erupted in conjunction with the effects of the atomic bomb and other future weapons. One of the questions posed to Dr. Bush was the possibility of forty atomic bombs being planted in the United States and detonated at the same time. Senator Brien McMahon (D-CT), the chairman of the Committee asked Bush if it was unrealistic to carry an atomic bomb in

\footnotetext{
${ }^{32}$ Robert Littell, "What the Atomic Bomb Would Do to Us," The Reader's Digest 48 (April 1946): 125-129.

33 "Defense in Atomic Age: Plans for Big U.S. Forces," U.S. News and World Report, September 28, 1945, pp. 22-23.

34 "Is Another World War Near? Growth of 'Big 3' Dissension," U.S. News and World Report, March 22, 1946, pp. 19-21.

35 "Can our Civilization Survive the Atomic Bomb?" Look, October 30, 1945, p. 71.

36 "Science," Time, November 28, 1949, p. 66.

${ }^{37}$ G. Brock Chisholm, “Can Man Survive?” The Nation, July 27, 1946, pp. 93-96.
} 
the United States in sections. ${ }^{38}$ It was even suggested that citizens move away from the coast and "barrow under inland mountain ranges."39 In his article in The Reader's Digest, de Seversky wrote that the "atomic bomb hysteria" was contributing to fantasy and speculation. "Fantasy is running wild. There are those that think we ought to dispense with all other national defense. They talk of a dozen suicides who will put on false whiskers, take compact atomic bombs in suitcases, and blow this country to bits. ${ }^{, 40}$ It is worth noting that even before the dropping of the atomic bomb, George Fielding Eliot wrote in his article for Foreign Affairs an apocalyptic account of the future if mankind were to continue on the path of destruction. Eliot wrote, perhaps in an unconscious reference to H.G. Wells's 1896 novel The Time Machine, "If we continue to wage wars, more and more men will have to burrow into the bosom of the earth for safety, leaving the open air and sunlight in which mankind has thrived."

Paradoxically, the atomic bomb gave the United States the temporary security it sought by ending World War II, but at the same time the atomic bomb developed in Americans a great sense of fear and insecurity about the future because of its tremendous leap in scientific warfare and technology. William L. Laurence, an authority on atomic research, wrote in the Saturday Evening Post:

One of the greatest dangers facing us and the world today comes, paradoxically enough, from the fact that while we posses the atomic bomb, we at the same time recoil from the very thought of ever using it except as a desperate, last-resort, measure of retaliation against an unprovoked attack. Despite this great psychological barrier that may lead to or undoing, the

\footnotetext{
38 "Optimism on Atomic Bomb," U.S. News and World Report, December 14, 1945, pp. 89-95.

39 "Atomic Force in War and Peace: Sequel to Bombing of Japan," U.S. News and World Report, September 7, 1945, pp. 28-29.

${ }^{40}$ de Seversky, “Atomic Bomb Hysteria,” p. 121-126.

${ }^{41}$ Eliot, "Science and Foreign Policy," Foreign Affairs, p. 378-387.
} 
mere knowledge of our exclusive possession of the bomb has, nevertheless, produced in a large number of our people a sense of security that may not be justified by the facts, now hidden behind an atomic curtain as impenetrable as its iron counterpart. ${ }^{42}$

The coupling of atomic bombs with the longer-range and faster speeds of jet engines meant that "the possibilities were truly terrifying." $" 43$ The close of World War II brought with it the age of total war, and concludes Hogan, it "was essential to maintain the armed forces in a state of constant readiness. UMT [the Truman administration believed] would provide that readiness, thereby enabling the country to meet its global commitments, discourage aggression, and defeat aggressors if deterrence failed." ${ }^{44}$

President Roosevelt urged congressional action on a program of universal military training in January 1945. With his death, this project was handed to Truman, who actively endorsed it. Although Truman's tough attitude with Molotov had not been made public because of its possible impact at home and abroad, it was evident among those that testified to Congress that it was a distinct possibility that the Soviet Union would become the future enemy of the United States.

By March, numerous editorials were branding UMT with the word "conscription." Harper's Magazine, in "Conscription for Peacetime," questioned the introduction of UMT as well as the military leaders' reasoning behind it. ${ }^{45}$ A Select Committee on Postwar Military Policy began listening to citizens and organizations both for and against universal military training in June. J. Brumbaugh, Vice President of the

\footnotetext{
${ }^{42}$ William L. Laurence, "How Soon Will Russia Have the A-Bomb?" The Saturday Evening Post, November 6, 1948, p. 23.

${ }^{43}$ Friedberg, In the Shadow of the Garrison State, pp. 36-37.

${ }^{44}$ Hogan, A Cross of Iron, p. 123.

${ }^{45}$ Hanson W. Baldwin, “Conscription for Peacetime?" Harper's Magazine 190 ( March 1945): 289300 .
} 
American Council on Education, used the word conscription in place of universal military training when he testified before the committee. Not only did the committee question him about his word choice, but also a full discussion about the meaning of conscription ensued. This conversation made it clear that Committee members did not approve of "conscription" when describing UMT, nor did they want the word to be used. $^{46}$ An editor and publisher from Indiana stated that universal military training had a harmless sound, "not blunt and arresting like 'peacetime conscription,' but that is what it really is." ${ }^{47}$ The term conscription was regularly used in place of universal military training through the end of the hearings. The enactment of UMT, opponents feared, "would enable the military to manipulate the labor market and forge an alliance of labor and military interests with a vested stake in defense expenditures, the arms race and war," therefore allowing an unwanted growth in government power. ${ }^{48}$

Women opposed to UMT were more concerned about its inhibiting world peace than they were about it ability to increase government power; however, women did not want the government to replace the role of the family and church. The women that opposed UMT felt that a constant preparedness would undermine American credibility. A common concern was the United States was taking on the responsibilities of the United Nations. Not all women were against UMT; many were for it. The United States was the leader of democracy, those in favor of universal military training believed, and it was the

\footnotetext{
${ }^{46}$ U.S. Congress, House, Hearings Before the Select Committee on Postwar Military Policy Pursuant to H. Res. $465,79^{\text {th }}$. Congress, $1^{\text {st }}$ sess., Part 1. June 1945 (Washington, D.C., 1945), pp. 103-105. (Hereafter House, Hearings).

${ }^{47}$ Ibid., p. 430.

${ }^{48}$ Hogan, A Cross of Iron, p. 133.
} 
moral obligation of all Americans, whatever the sacrifice, to free the world from oppression. $^{49}$

"Does the future national security require universal military training?" was the question of the week in the November 2, 1945 issue of U.S. News and World Report. Dr. Ellsworth Huntington, assigned to Military Intelligence in the U.S. Marine Corps, responded by saying that the Russians would think that the primary reason for the United States to enact universal military training would be in retaliation against them. ${ }^{50} \mathrm{Dr}$. Troyer A. Anderson, Office of the Under Secretary of War, stressed, "Hereafter, defense must be a primary consideration."51 Byrl A. Whitney, Director of Education Research and Assistant General Counsel, Brotherhood of Railroad Trainmen, testified to the Select Committee on Postwar Military Policy: "If we are going to destroy completely the warmaking powers of Germany and Japan, then the conclusion is forced that we are preparing for the next war against one or more of our present Allies.. ${ }^{, 52}$ Major General Ellard Walsh, President of the National Guard Association of the United States, stated in his argument for the enactment of UMT that it was essential to the future security of the United States: if "Russia finds it imperative to establish such a system at this time, then how can the people of this Nation ignore the issue? It would seem that we have no choice but to do in like manner."53 But Roscoe S. Conkling, a well-known New York attorney, argued the opposite view. He contended that the Soviet Union might have

\footnotetext{
${ }^{49}$ John Fousek, To Lead the Free World: American Nationalism and the Cultural Roots of the Cold War (Chapel Hill and London, 2000), pp. 111-113.

50 "Question of the Week", U.S. News and World Report, November 2, 1945, p. 48.

51 "Reassurance on the Atom," U.S. News and World Report, December 21, 1945, p. 27.

${ }^{52}$ House, Hearings, p. 170.

${ }^{53}$ Ibid., p. 55.
} 
started conscription for their fourteen- and fifteen-year-olds in reaction to the proposal of universal military training by the United States. ${ }^{54}$ Through out the hearing, there was a discourse of fear.

A statement by the editor of the Arizona Daily Star, William R. Mathews, pointed out the possibility that the Soviet Union would dominate Eastern Europe by setting up satellite governments, therefore making the Soviet Union "master" of that region. Mathews further stated that this development meant, "that the Soviet Union succeeds Germany as the dominant power in Europe ... [and] the security and independence of our country requires that we prevent the development of an overwhelmingly dominant power in Western Europe." Mathews questioned the ambitions of the Soviet Union throughout his presentation and used doubts about the Russians in advocating the immediate enactment of UMT. The Select Committee's report summarized Mathews's views in the following way: "Russia has definite designs on Western Europe, on England, and after that on the United States, and that if it is strong enough to accomplish these designs it will do so." 55 Judge William Hastie of the National Association for the Advancement of Colored People noted, "No thinking person can avoid grave concern as he observes signs of increasing distrust between the two nations with greatest resources and influence today, the United States and Russia." ${ }^{, 56}$ In summary of the second day of the hearings of the Select Committee on Postwar Military Policy, Leo E. Allen (IL) commented: "It is obvious to me that every witness, including Mr. Joseph Grew of the

\footnotetext{
${ }^{54}$ Ibid., p. 222.

${ }^{55}$ Ibid., p. 65-66, 69.

${ }^{56}$ Ibid., p. 113.
} 
State Department, who are sponsoring this program are fearful of but one nationRussia."57

The idea of universal military training had been circulating in Congress and among members of government since the start of the First World War; however, it was not rigorously investigated until 1945. The strongest proponents for UMT were those that remembered the lack of preparedness and the isolationism of the United States before both World Wars. In their arguments, they noted that there would not be sufficient time for the United States to prepare should there be another war. Because the United States was now the world's most powerful nation, it needed to be prepared at all costs and for any event. What was being argued, in effect, was how to protect freedom and democracy through military power and technological might. Acting Secretary of State Joseph C. Grew said in his remarks to the committee, "We must be strong if we would be free.... We are civilians very deeply interested in the future security of our country, and I believe very deeply that our preparedness will discourage potential aggressor nations and will also help to maintain world peace." ${ }^{, 5}$ John Thomas Taylor of the American Legion argued that after the Great War "there was a feeling of false security which has been a dangerous American characteristic, [and] the fact remains that the lessons of war were soon forgotten." He further argued, had the United States enacted UMT, “the war-mad dictators would not have judged us as a 'soft, unprepared' nation." One of the goals of the American Legion through UMT was the ability to train men for

\footnotetext{
${ }^{57}$ Ibid., p. 89.

${ }^{58}$ Ibid., p. 5,6.
} 
the armed forces in such a way that any aggressor nation "would not dare wage war against the United States." 59

Both Secretary of War Henry L. Stimson and General Dwight D. Eisenhower defended the enactment of UMT to the Select Committee on Postwar Military Policy. Stimson argued that it was fear of initiating a war that made the American public doubt the advisability of universal military training. UMT, in his opinion, was not going to bring the country to war. Eisenhower noted that more than any factor, the number of men available to bear arms was the most important consideration when fighting a war. Eisenhower did state, however, that "training is an obligation to the state, and to the individual himself." 60 This statement seemed to confirm one of the main points that those opposed to UMT had argued, namely, the control of the country and its citizens through the armed forces. It is important to note that both Stimson and Eisenhower, perhaps sensitive to these sentiments, did not attribute the necessity of enacting UMT to national security.

In these pre-atomic hearings of the Postwar Military Policy Committee, it is also worth noting that several members who testified against universal military training used the advancement in weapons technology in their reasoning. Byrl A. Whitney asserted that in the future "technology and science will fight wars."61 The Reverend T. T. Brumbaugh, Executive Secretary of the Detroit Council of Churches, used the same reasoning in his statement against UMT. Brumbaugh told the Committee that "future wars will not be won only by military manpower but will be won by technological and

\footnotetext{
${ }^{59}$ Ibid., pp. 37,39,42.

${ }^{60}$ Ibid., p. 487.

${ }^{61}$ Ibid., p. 172.
} 
chemical proficiency, and the United States should see to it that provisions are made for discoveries and such inventions will protect America." ${ }^{22}$ In his statement opposing UMT, Socialist Norman Thomas of the Postwar World Council, said not only would the conscripted men not be prepared within the year of training currently proposed, but they "would be useless against the first impact of a third world war begun by surprise attack from the air by rocket bombs and other new developments." ${ }^{\text {63 }}$ Judge William Hastie testified that he thought civilization could not survive another war. ${ }^{64}$

Throughout 1945 and 1946, debates over universal military training questioned its practicality. The first priority of the Select Committee on Postwar Military Policy was to recommend whether UMT should be enacted before the end of the war. Although an extension of the draft was also a possibility, a revision of the draft became the focus. And as time passed, the means and desired goals of UMT changed. ${ }^{65}$ Not only did atomic power come into play, but also the mass destruction of major cities across the globe emphasized the new international role of the United States. Editorials tried to put into perspective for readers what UMT actually entailed. Those in favor of UMT not only presented the security reasons, but they also argued the physical and mental benefits to young men. In the Winter 1945-46 Issue of Public Opinion Quarterly, more than three-quarters of those polled believed in the effectiveness of UMT. ${ }^{66}$ Given the conscription-UMT controversy, that percentage might seem surprising.

\footnotetext{
${ }^{62}$ Ibid., p. 183.

${ }^{63}$ Ibid., p. 227.

${ }^{64}$ Ibid., p. 111.

65 "Plan to Revise the Draft," U.S. News and World Report, October 4, 1946, p. 15.

66 “The Quarter's Polls," Public Opinion Quarterly 9 (Winter 1945-46): 521-523.
} 
To those in attendance at the House Committee hearings on UMT, the apparent contradiction had been explained nicely by Representative Everett Dirksen (R-IL), "Oddly enough, the arguments that I have examined both for and against compulsory military training spring from the same universal passion, namely fear. Fear seems to persuade those who favor it and those who oppose it."67 Supporters feared another war, whereas opponents feared the growth of government power in the name of security.

The opening months of 1947 brought the deterioration of stability in Greece and Turkey. British aid to both countries was no longer possible. Under Secretary of State Dean Acheson told Congress:

Soviet pressure on the Straits, on Iran, and on northern Greece had brought the Balkans to the point where a highly possible Soviet breakthrough might open three continents to Soviet penetration...The Soviet Union was playing one of the greatest gambles in history at minimal cost. It did not need to win all the possibilities. Even one or two offered immense gains. We and we alone are in a position to break up the play. These are the stakes that the British withdrawal from the eastern Mediterranean offered to an eager and ruthless opponent. ${ }^{68}$

The ideology behind the call for Congressional action was that of national security. The fear was that if Greece and Turkey were to slip from the Anglo-American orbit, they would slide into the orbit of the Soviet Union and become additional communist satellites. If this should occur, the President said in a speech before Congress, the capitalist system of the United States would be in jeopardy. President Truman gave economic reasons for the proposal of the Truman Doctrine in March 1947. In his speech, he explained that "Americans, if they hoped to preserve their personal freedom,

\footnotetext{
${ }^{67}$ House, Hearings, p. 590.

${ }^{68}$ Dean Acheson, Present at the Creation: My Years in the State Department (New York, 1969), p.219.
} 
had to rebuild the areas west of the Iron Curtain before those lands collapsed into anarchy, radical governments, or even communism." Communist infiltration of any government was a direct threat to American national security. Robert Taft, Senate Republican leader was afraid that Truman was dividing the world into two spheres: communist and anti-communist; and Taft said that he did not want war with the Soviet Union. Liberal Henry Wallace said that the Truman Doctrine would create a "century of fear." As Walter LaFeber has explained, the Truman Doctrine "used the American fear of communism both at home and abroad to convince Americans that they must embark upon a Cold War foreign policy."

When Secretary of State George Marshall was in attendance at the Moscow Council of Foreign Ministers meeting in the spring of 1947, Stalin said he was convinced of a European economic collapse. Shaken, Marshall returned to the United States to propose monetary aid to Europe; American capitalism would be unable to survive without European purchases. In his commencement speech at Harvard, Marshall invited European governments to produce an acceptable recovery plan and the United States would provide the funding. His address was the introduction of the Marshall Plan. ${ }^{70}$

While Truman was seeking congressional and popular support for the Truman Doctrine and the Marshall Plan, rumors were circulating in the American press about the Soviets "purchasing" German atomic scientists. "Bold headlines," one article read, "shocked U.S. newspaper readers once again this week into the conviction that the

\footnotetext{
${ }^{69}$ Walter LaFeber, America, Russia, and the Cold War, 1945-1990, $6^{\text {th }}$ ed. (New York, 1991), pp.5257.

${ }^{70}$ For a full explanation of the Marshall Plan see Michael J. Hogan, The Marshall Plan: America, Britain, and the Reconstruction of Western Europe, 1947-1952 (Cambridge, 1987). Also see Melvyn Leffler's A Preponderance of Power.
} 
American secret of the atomic bomb is coveted by only a single scheming rival"- the Soviet Union. Articles in the New York Times and European newspapers had "confirmed" this story, a story that turned out to be false. ${ }^{71}$ Public Opinion Quarterly found that seventy-five percent of the American population believed that atomic bombs would become more powerful in the near future. ${ }^{72}$ But atomic bombs were not the only weapons Americans needed to fear. Leonard Engel made this clear in his article in The Nation about biological warfare. He explained biological warfare and how it was designed to release diseases to humans, plants and animals. Engel stressed that, in his estimation, atomic control was not as important as building trust and friendship between rival countries because another war would bring with it new, incredibly destructive weapons. $^{73}$

The year 1947 also brought with it an experimental camp in Ft. Knox, Kentucky for universal military training. The importance of UMT was stressed by Secretary of War Robert P. Patterson in an article in The Saturday Evening Post. Patterson emphasized the urgency of enacting UMT, which would be a prudent response to the uncertainty of the future of the world. Patterson urged Americans to embrace universal military training because of "sheer national necessity." Patterson explained the need for UMT by placing it in a national security context:

If the United States again drifts back-and the drift had begun-- to a policy of military weakness, then we are in danger of enslavement or extinction as a nation within the lifetime of most Americans now living. The oceans no longer guarantee us protection. Our monopoly of the atomic bomb is

\footnotetext{
71 “Atomic Scoop," New Republic, March 3, 1947, p. 6.

72 "The Quarter's Polls," Public Opinion Quarterly 10 (Fall 1946): 401.

${ }^{73}$ Leonard Engel, "The Scope of Biological Warfare," The Nation, July 26, 1947, p. 93.
} 
temporary. . . . A surprise knockout blow against this country is already a scientific possibility. ${ }^{74}$

When the draft expired on March 31, 1947, UMT was again before Congress. According to U.S. News and World Report the revival of UMT "was encouraged by growing tensions in world affairs." But the plan for UMT had changed from two years to one. The first six months of training would include military tactics in an army-like boot camp close to home. The second six months would be the choice of the trainee. The options would consist of serving in the National Guard, special training in a technical field, taking college ROTC courses, or enlistment. Exemptions would be few. The physical and mental requirements were lower than the armed forces required. This was what U.S. News and World Report termed the new "master plan" for the future protection of the nation. ${ }^{75}$

Yet the public was still questioning whether universal military training would provide enough security for the United States. U.S. News and World Report continued to emphasize the precarious position of the country. In June, the magazine reported, "The United States is the world's one really rich nation. This country is the envy of a poverty-stricken world and the recognized object of any future military attack." The government would pay for the decentralization of industries as well as underground war plants. The article also noted that government offices would move underground in the event of war. $^{76}$ An editorial in the New Republic observed that, in the current environment of fear, it would be more beneficial to national security to move factories

\footnotetext{
${ }^{74}$ Robert P. Patterson, "We Must Have Military Training-Now!" The Saturday Evening Post, April 26, 1947, p. 26.

75 "Peacetime Draft: 6-Month Plan," U.S. News and World Report, March 28, 1947, p. 13.

76 "War Drill for All Youths?" U.S. News and World Report, June 13, 1947, p. 15.
} 
underground than to support UMT. The editorial also questioned the effectiveness of UMT in a nuclear age:

If 40 million Americans are to be killed overnight in an atomic war, what will young men trained to run over obstacle courses, to observe the niceties of military etiquette and to dismantle machine guns, accomplish? Doctors, nurses, firemen, water-supply experts, Geiger-counter operators were needed at Hiroshima. ${ }^{77}$

After a six-month investigation, the Advisory Commission on Universal Military Training handed its result to President Truman. The members had unanimously concluded that UMT was essential to national security. One of the reasons for this decision was the development of the atomic bomb and its effect in warfare. ${ }^{78}$ The results of the report were published in Newsweek. Not only did the Committee predict that the United States would lose its atomic monopoly by 1951, it also reported that an atomic attack was likely by 1955 . Graphic details of destruction by atomic, "bacteriological" and chemical weapons would be likely. Although the war would be short, it would come suddenly, the report said, and "the signal for the start of the war against us would be a large-scale, long-distance onslaught with atomic explosives against our principal centers of population and production." Supporting UMT, the commission said that the current armed forces of the United States were but "a hollow shell." The conclusion of the committee was that UMT was not only important, but also "essential" to national security. ${ }^{79}$

\footnotetext{
77 "Editorial," New Republic, June 23, 1947, p. 11.

${ }^{78}$ Harry S. Truman, Years of Hope, vol. 2 of Memoirs By Harry S. Truman (Garden City, 1956), pp. 53-54.

79 "War and UMT," Newsweek, June 9, 1947, p. 24.
} 
The controversy surrounding UMT continued. Journals of opinion questioned the U.S. government about its propagation of fear of communism. The Nation especially examined several instances of government interference in what had long been private matters. In the January 17, 1948, issue The Nation, charged that the government was dismissing scientists from their positions because of their affiliation, or supposed affiliation with communist organizations. ${ }^{80}$ A month later, the same periodical insinuated that the United States was headed "[t]oward World War III." It reported that the publication of documents by the State Department on "Nazi-Soviet Relation, 1939-41," was incomplete, and charged that its sole purpose was "to build up fear and hatred of the U.S.S.R." The article further claimed, "Volumes of this kind are commonly published by governments when war is about to start or has already begun." 81 In March, the government began to pursue the deportation of communist leaders within the United States. The Nation noted "the deportation warrants charge them with being or having been members of an organization that advocates 'the overthrow of the United States [government] by force and violence." ${ }^{82}$ Communists, The Nation said the government implied, were encircling the American people. The concerns raised by The Nation, instead of calling officials to account, actually assisted the administration's effort to build support for its foreign policies by spreading alarm over the government's actions and its anti-communist propaganda.

In January 1948, Congress began investigating UMT propaganda in the War Department. Testifying before the House Committee on Publicity and Propaganda,

\footnotetext{
${ }^{80}$ Leonard Engel, "Fear in Our Laboratories," The Nation, January 17, 1948, p. 63.

${ }^{81}$ I.F. Stone, "Toward World War III," The Nation, February 7, 1948, p. 146.

82 "The Deportation Cases," The Nation, March 13, 1948, p. 291.
} 
Frank T. Bow, the General Counsel to the Committee, said that that the UMT Pioneer, the Fort Knox camp newspaper, was written not to appeal to the trainee, but to appeal to "sell the virtue of UMT:" No opposing views were represented. Furthermore, the Department of the Army was propagating UMT through public speaking engagements and tours while using Federal funds to do so. Secretary of the Army Kenneth C. Royal defended the Army by telling the Committee that UMT propaganda was merely a byproduct of the Army's stated personnel needs. ${ }^{83}$ Americans feared that the Army was already increasing its power through government. This was one of the very reasons for those opposed to the enactment of UMT.

Within months of the Commission's final report, communists seized power in Czechoslovakia, an event that was arguably constitutional and free from violence. ${ }^{84} \mathrm{But}$ in the eyes of the Truman administration, Czechoslovakia had fallen to communism by means of a coup. And soon after their seizure of power, the communist government closed down anti-communist newspapers and periodicals and had "non-[c]ommunist ones purged during the next few days, followed shortly by universities, professional bodies, sports clubs, the publishing industry, and the civil and military services." Soon thereafter, all companies with more than fifty employees were nationalized. ${ }^{85}$ The seizure appeared to have taken U.S. officials by surprise. But according to Carolyn

\footnotetext{
${ }^{83}$ U.S. Congress, House, Hearings Before the Committee on Expenditures in the Executive Departments: Investigation of War Department Publicity and Propaganda in Relation to Universal Military Training, Pursuant to H. Res. 90 and 197, $80^{\text {th }}$ Congress, $2^{\text {nd }}$ sess. January 14,1948 (Washington, D.C., 1948).

${ }^{84}$ Joseph Rothschild and Nancy M. Wingfield Return to Diversity: A Political History of East Central Europe Since WWII, $3^{\text {rd }}$ ed. (New York, 2000), p. 94. Historian Vojtech Mastny gives very little description of the communist seizure in Czechoslovakia, but refers to the incident as a coup. Vojtech Mastny, The Cold War and Soviet Insecurity: The Stalin Years (New York, 1996), p. 44.

${ }^{85}$ Ibid., p. 95.
} 
Woods Eisenberg, author of Drawing the Line: The American Decision to Divide Germany, 1944-1949, American officials were expecting communist activity in Czechoslovakia, and "[p]rivately, there was less shock and upset than was being projected to the American public." The CIA reported that the coup was not a gauge of sudden Soviet capabilities, but the "psychological reaction to the Czech coup appears to have been out of proportion to its actual significance." 86 Because of the overreaction of the Truman administration, however, the American public was stunned. The Truman administration projected the unrealistic fear that other governments in Europe would follow the Czech example. American officials used this action to exemplify the importance of UMT. If Congress enacted universal military training, it would not only "demonstrate resolve," but also assure Europeans that the United States would not pull out of Europe should another war occur. ${ }^{87}$ In his diary, the first secretary of defense, James Forrestal, wrote "the important thing is to get the adoption of UMT in order to make inescapably clear both to our friends and non-friends that there is a continuity, firmness and will behind our foreign policy." 88

Shortly after, in his speech before a joint session of Congress on the morning of March 17, 1948, President Truman again urged recognition of the importance of the European Recovery Program (Marshall Plan), the enactment of UMT and adopting the

\footnotetext{
${ }^{86}$ Carolyn Woods Eisenberg, Drawing the Line: The American Decision to Divide Germany, 19441949 (New York, 1996), p. 369 fn; Arnold Offner also states that the Communist seizure of power in Czechoslovakia was no surprise to the Truman administration, but was warned almost a year prior by George Kennan that this was a possibility. Offner, Another Such Victory, p. 237.

${ }^{87}$ Leffler, Preponderance of Power, pp. 205-209.

${ }^{88}$ Millis, Forrestal Diaries, p. 384.
} 
selective service. ${ }^{89}$ On this occasion Truman, writes Michael Hogan, "compared Stalin to Hitler and [said] that the tragic death of the Czech Republic was only the latest example of world wide Communist aggression." The American public was called upon to "accept their mission as defenders of democracy," as well as make the necessary sacrifices to employ a larger military establishment. ${ }^{90}$ It would not be too much to claim that Truman believed it was the manifest destiny of the United States to save the world from communism. In less than two weeks, Congress approved the Marshall Plan and passed a Selective Service bill. ${ }^{91}$ The more comprehensive and controversial universal military training bill was still sitting in Congress, however.

In reaction to the speech President Truman made to Congress, The Nation said the President was "needlessly provocative," and that the enactment of peacetime conscription in the United States would be a violation of "very deep traditions and habits of mind." The Nation suggested finding a peaceful means of mending the relationship between the United States and the Soviet Union, one which would not entail UMT. Because the President's speech coupled ERP with UMT and selective service, wrote Freda Kirchwey in The Nation, Truman implied that what he was calling for was an enlarged Truman Doctrine to save Western Europe from communism. ${ }^{92}$ Time reported that the President's speech made Congressmen realize that this was only the beginning "in a new, cold and hard-broiled U.S. foreign policy." And although the American

\footnotetext{
${ }^{89}$ Melvyn P. Leffler, The Specter of Communism: The United States and the Origins of the Cold War, 1917-1953 (New York, 1994), p. 77.

${ }^{90}$ Hogan, A Cross of Iron, p. 147.

${ }^{91}$ LaFeber, America, Russia, and the Cold War, 1945-1990, p. 73.

${ }^{92}$ Freda Kirchwey, "The President's Message," The Nation, March 27, 1948, p. 341.
} 
people were "just plain scared," they were "resigned to the idea that 'we've got to stop Russia." 93

On the afternoon of March 17, Senator John Chandler "Chan" Gurney (R-SD), acting Chairman, told the Senate Committee on Armed Services that it was the Committee's intent to not only investigate the country's need for UMT, but primarily to do what was necessary and mandatory for the best interest of the United States. This statement was made in the context of deteriorating relations with, and aggression by, the Soviet Union. "It is perfectly clear that a definite threat to our own security exists in the world today: it is clear that the clouds if war are starting to gather," Gurney said. ${ }^{94}$ The proof to the administration was the Czech coup: it lent credibility to the administration's endorsement of UMT. As the opening speaker, Secretary of State George C. Marshall began his testimony by observing the United States was in a precarious world situation and was not militarily prepared. As before, Marshall highly endorsed UMT to the Committee. Marshall and Forrestal urged the necessity of UMT in response to dangerous communist developments abroad. ${ }^{95}$ The Truman administration exaggerated the Soviet expansionist tendencies to justify to Americans the urgency of enacting UMT.

The Nation encouraged a discourse on universal military training and carried both views in a number of articles. On April 17, "Why I Oppose U.M.T." was published. The author was the president of Sarah Lawrence College, Harold Taylor. He opposed UMT, not only because it would interfere with the education of young men, but also because it

\footnotetext{
93 "National Affairs," Time, March 29, 1948, p. 21.

${ }^{94}$ U.S. Congress, Senate, Hearings Before the Committee on Armed Services on Universal Military Training, $80^{\text {th }}$ Congress, $2^{\text {nd }}$ sess., March and April 1948 (Washington, D.C., 1948), pp. 1-4.

${ }^{95}$ Hogan, A Cross of Iron, p. 146.
} 
would lead Americans as a whole to believe the conviction by "both the United States and Russia that only the threat and use of national military power operat[ing] outside the structure of the United Nations can bring about a stable world order." Furthermore, Taylor said, "The question of military training is actually that of whether or not there is any way of organizing world peace other than by threatening to fight Russia." Taylor continued that no argument had been put forth to demonstrate that without conscription the national security of the United States was jeopardized or that "communism in Europe will be contained by drafting eighteen-year-olds in America." According to Taylor, the United States already had the most efficient military force in the world, and insufficiently trained young men could not curtail aggressors. To contain communism, Taylor wrote, "We must avoid the negative solution of the military threat, along with refusal of aid to those who need it." 96 With the already charged international political atmosphere, it was feared, the enactment of UMT would only provoke another war

The following week The Nation printed an opposing view. William L. Blatt, Jr., research director of the Democratic National Committee and a veteran of WWI, wrote, "Why I advocate U.M.T." Blatt argued that wanting UMT was not the question at issue. Because of the aggression the Soviet Union had demonstrated throughout the world, it was the duty of the United States to protect the freedom and personal rights of individuals in threatened countries. According to Blatt, the United States was the only country strong enough to do the job. In his closing statement, Blatt wrote, "U.M.T. and the draft will not guarantee peace, but as key parts of the program for the defense of the

\footnotetext{
${ }^{96}$ Harold Taylor, “Why I Oppose U.M.T.” The Nation, April 17, 1948, p. 410.
} 
free world they will give us a better than even chance of upholding the peace in the immediate future. Whatever they cost, it will be small price to pay for that chance. ${ }^{, 97}$ In a slightly different take on the question of UMT, Richard W. Bolling of the American Veteran's Committee, wrote to the editor of The Nation that modern war is total war, and to conscript young men and require them to put their lives on the line was not justified when other civilians were not called upon to do the same. Bolling further noted that those who were not conscripted could essentially lead their lives unchanged. All American citizens, he felt, should make a "patriotic sacrifice."98 But as the hearings came to a close, both the Senate and the House had lost interest in UMT. The "war scare" that was created by the Czech coup was beginning to fizzle and nothing was done about UMT. After mid-1948, UMT would never again be a major issue for the Truman administration.

As the Czech war scare subsided, American-Soviet tensions in Germany escalated. On June 24, all traffic from the Western zones of Germany to Berlin was curtailed by the Soviets. This action was in response to the decision to merge the American, British, and French zones to create a Federal Republic of Germany. Only four days later Truman responded to the Berlin Blockade by saying, "We [are] going to stay, period." With this declaration, the United States began airlifting to Berlin up to 13,000 tons of supplies per day. To demonstrate American resolve, Truman sent two groups of B-29 bombers to England. These planes were designed to carry atomic weapons. Although the Americans had only a few dozen atomic weapons, the Soviets had none. According to

\footnotetext{
${ }^{97}$ William L. Blatt, Jr., “ Why I Advocate U.M.T.," The Nation, April 24, 1948, p. 439.

${ }^{98}$ Letters to the Editor, The Nation, May 1, 1948, p. 514.
} 
LaFeber, "The President assured Forrestal and Marshall that, although he prayed the bomb did not have to be used; 'if it became necessary, no one need have a misgiving but what he would do so.",99 Although a direct threat of atomic usage did not accompany the B-29's, the unspoken rhetoric was there. Truman was relying on an atomic arsenal "as a means of deterring the Russians." 100 In his statement to European diplomats at the Foreign Ministers Meeting in the fall of 1948, Marshall, Melvyn Leffler concludes, "discreetly alluded to the atomic monopoly as the West's trump card. Atomic weapons were not only critical for warfare; they were indispensable in peacetime. . ."101 Stalin ultimately retreated, and in May 1949 the blockade was abandoned.

Three months later, the Soviet Union detonated its first atomic device, and the Cold War's climate of fear would again be in evidence.

\footnotetext{
${ }^{99}$ LaFeber, America, Russia and the Cold War, 1945-1990, pp.76-77.

${ }^{100}$ John Lewis Gaddis, We Now Know: Rethinking Cold War History (Oxford, 1997), pp. 91-92.

${ }^{101}$ Leffler, The Specter of Communism, pp. 84-85.
} 


\section{Chapter 2}

\section{The Soviet Atomic Bomb}

At 10:30 a.m. September 23, 1949, President Truman's Press Secretary Charles Ross had the news correspondents enter the room. Before distributing the bulletin, Ross announced that no one was allowed to leave the room until everyone had read the statement that he was about to pass out. A Secret Service man closed the door. As the newsmen started skimming the story, someone yelled out, "My God, the Russians have the bomb!" With that announcement, the men ran out the door. ${ }^{1}$

Although the Berlin Blockade had ended, the war scare did not dissipate. The press was reporting on the military build-up of the Soviet Union and continued to question whether the United States was ready for another war. In early July 1949, U.S. News and World Report tried to downplay the war scenario by emphasizing Soviet preparedness for defensive rather than aggressive reasons, while at the same time it described the strength and numbers of the Soviet armed forces. ${ }^{2}$ The same periodical assured Americans that the United States had enough bombs to destroy at least eighty-one of Russia's most populous cities and provided a map to mark each city. ${ }^{3}$ Thus, even before the United States became aware that the Soviet Union had atomic capabilities, the press was fabricating World War III scenarios. According to James Aronson, author of The

\footnotetext{
1 "Why We Told," Newsweek, October 3, 1949, p. 18.

2 "Why War Scare is Ending: Russia's Shift to Defensive," U.S. News and World Report, July 8 , 1949, pp.11-12.

3 “How Many Atom Bombs?" U.S. News and World Report, July 1, 1949, pp. 22-23.
} 
Press and the Cold War, "by March 1948, the Gallop Poll reported that 73 percent [of the American public] believed that a third world war was inevitable."4

President Truman, in his July 25 address to Congress, blamed the difficulties of European recovery on Soviet aggression. This aggression, explained Truman, was disrupting the peaceful conditions the world was seeking, and in its place, "the Soviet Union, with its violent propaganda, its manipulation of conspiratorial activities of the world Communist movement, and its maintenance of one of the largest peacetime armies in history, had deliberately created an atmosphere of fear and danger." ${ }^{5}$ Within one month of Truman's speech to Congress, U.S. News and World Report was speculating about how the United States was going to wage the next war. A two-page visual explanation of where atomic bombs were to be dropped within the Soviet Union accompanied the article. ${ }^{6}$ Regardless of the American success in response to the Berlin Blockade, there was still a feeling of an inevitable conflict with the Soviet Union. Periodicals regularly depicted war scenarios and relayed strategic information for American success. Three days after the publication of this article, the Soviet Union detonated its first atomic device. What this event meant for U.S. foreign policy and the discourse of fear in America's Cold War are the subjects of this chapter. ${ }^{7}$

\footnotetext{
${ }^{4}$ James Aronson, The Press and the Cold War (Indianapolis, 1970), p. 37. Aronson also quotes historian D.F. Fleming: "The conversion to a war mentality was already well along.... throughout this period most of the press continued to fan the war fever," p. 37.

5 "To Thwart Russia's Aggression: Message by President Truman to the Congress," U.S. News and World Report, August 5, 1949, pp. 40-41. It is interesting to note that in 1949, the Truman administration was still strongly encouraging the enactment of UMT.

6 "How U.S. Will Fight Next War: Air Attack Only a Beginning," U.S. News and World Report, August 26, 1949, pp. 11-14.

${ }^{7}$ For one look at the domestic context in which these events unfolded see: Elaine Tyler May, Homeward Bound: American Families in the Cold War Era, rev. ed. (New York, 1999), pp. 81ff. Interestingly, the title of the chapter is "Explosive Issues: Sex, Women, and the Bomb."
} 
During the early years of his presidency, Harry S. Truman was a hesitant and reluctant leader, often telling advisors that he never wanted the job. In relating his meeting with Molotov to former ambassador to the Soviet Union, Joseph E. Davies, Truman said, "I gave it to him straight. I let him have it. It was the straight one-two to the jaw." Then he asked, "Did I do right?" Not only was Truman unversed in foreign affairs, he was not familiar with wartime allied relations. Although he stated every intent to follow through with former President Roosevelt's policies, Truman began to formulate his own ideas about foreign policy—thoughts carefully molded by his advisors-especially where it concerned American-Soviet relations. Roosevelt had directed his own foreign policy and often did not take advise from his cabinet; these same men were more than eager to advice a new and uninformed president. During the course of Truman's presidency, his confidence increased. As Truman's self-assurance progressively grew, the administration's policies toward the Soviet Union became more unyielding.

Policy makers, although taking a more aggressive approach toward the Soviet Union than in the past, were not as assertive as they would later become. In 1947, the U.S. government was still dubious about perceived Soviet hostilities toward the United States. In response to anti-Soviet criticisms in Newsweek, Secretary of State George C. Marshall defended the free press of the United States to the Ambassador of the Soviet Union in his reaction to an article about the possible future aggression from the Soviet Union. Newsweek was defended because "the greater part of the article was devoted to

\footnotetext{
${ }^{8}$ Arnold A. Offner, Another Such Victory: President Truman and the Cold War, 1945-1953 (Stanford, 2002), p. 34.
} 
speculation concerning measures to which the United States might resort for its national defense if confronted with such an attack. There is no suggestion that the United States should take the initiative in attacking the Soviet Union or any other country." was almost apologetic, and the fact that Secretary Marshall felt that the free press of the United States needed defending is worth noting.

In the Soviet Union, during this same period, Josef Stalin was driving a hard campaign of Leninist ideology throughout Russia with emphasis on the denunciation of capitalism. The United States government followed closely the Soviet propaganda, but acted hesitantly in response. ${ }^{10}$ There was a constant stream of worrisome information coming from the American Embassy in Moscow. Ambassador Walter Bedell Smith did not hesitate to inform those in the White House about the "hardening anti-Western Soviet line." In reaction to anti-American propaganda, the State Department late in 1947 cautiously suggested that the United States should use education to counter Soviet actions but more importantly warned that the "[p]ropaganda patterns of the Soviet Union should not be imitated lest foreign peoples believe the U.S. is engaged in propaganda competition for world domination with the Soviet Union." To achieve this objective, the

\section{United States}

should not give the impression that it is on the defensive or vulnerable to hostile charges but rather that Soviet policy where it conflicts with ours works to the detriment of interests of the foreign country or area involved,

\footnotetext{
${ }^{9}$ The Secretary of State to the Ambassador in the Soviet Union, June 28, 1948, Foreign Relations of the United States, 1948, vol. 4: Eastern Europe; The Soviet Union: 896-898 (Hereafter, FRUS).

${ }^{10}$ The Ambassador in the Soviet Union to the Secretary of State, February 10, 1947, ibid.,530-531. A revised copy of the Short Biography of Stalin had been published in 1946, as well as the film "The Oath," both of which praised Stalin. Also see: Vojtech Mastny, The Cold War and Soviet Insecurity: The Stalin Years (New York and Oxford, 1996), pp. 23-39; Walter LaFeber, America, Russia and the Cold War, 1945-1990, 6th ed. (New York, 1991), p. 38; William Taubman, Stalin's American Policy: From Entente to Détente to Cold War (New York and London, 1982), pp. 171-173.
} 
while U.S. policy consistently supports principles implicit in the Charter of the United Nations. ${ }^{11}$

Although the administration would "expose" discrepancies, the State Department said, it would not use "personal vilification or abuse" toward Soviet and communist leaders. Throughout the year and into the next, the administration continually assured the Soviets that the United States had no aggressive tendencies toward Russia. With this cautious foreign policy in effect, President Truman, still apprehensive about American-Soviet relations in 1947, sent a telegram of salutation to the Soviet Union upon the national anniversary of the USSR. ${ }^{12}$

By the spring of 1948 , however, Truman and his advisors had become more assertive in their foreign policy tactics toward the Soviet Union. The Czech coup, the formation of the Cominform, and the growing tensions over Germany were contributing factors. Because the State Department was concerned that showing a sign of weakness might accidentally cause the Soviet Union to initiate World War III, it emphasized in a telegram to the American Embassy in Moscow that "any further encroachment by the Soviet Union, by countries under its control, or by communists parties dominated by it, beyond the present limits of communist power, would be regarded by this country as an

\footnotetext{
11 The Acting Secretary of State to Certain American Diplomatic Officers, December 8, 1947, FRUS, 1948, 4:630-631.

${ }^{12}$ The Secretary of State to the Embassy in the Soviet Union, November 5, 1947, FRUS, 1947, 4: 606. It was advised to the president that the telegram should not be sent in its entirety because of the "existing situation." Therefore, only the first sentence was sent: "On this national anniversary of the Union of Soviet Socialist Republics, please convey to the people of the Soviet Union the sincere greetings of the people of the United States." Until the beginning of 1948, Truman conveyed public hopes of good relations with the Soviet Union. In a speech on April 17, 1948, the president said publicly off the record that he had liked "Old Joe" and was disappointed to discover their different moral code- "if they have any [at all]," Alonzo L. Hamby, Man of the People: A Life of Harry S. Truman (New York, 1995), p.440.
} 
act of Soviet aggression." 13 On May 4, the Truman administration made its policies clear to the Soviet Union. In an exchange with Molotov, Ambassador Smith stated that although the United States did not have any hostile plans toward the Soviet Union, it would not tolerate current anti-American foreign policy. ${ }^{14}$ By the end of the month, the administration was re-evaluating American-Soviet relations and came to the conclusion that the United States was in the past overly generous and patient toward the Soviet Union with little or no impact. ${ }^{15}$ Carolyn Woods Eisenberg writes that the initial SmithMolotov meeting did not produce the desired effect. Instead of finalizing negotiations with Russia, Smith's ambiguity allowed for Molotov to seek further negotiations. To the States Department, the Russians were "palpably twisting Smith's strong demarche into a manifestation of weakness." This act in itself furthered the State Department's resolve to terminate perceived Soviet hostilities and propaganda. ${ }^{16}$ To this end, notes Richard M. Freeland in The Truman Doctrine and the Origins of McCarthyism, President Truman began to take a "bold and aggressive course" toward the communist issue. ${ }^{17}$

This change manifested itself in a number of ways, especially after the inception of the Berlin Blockade. Policy makers wanted to accord the "National Military

\footnotetext{
${ }^{13}$ The Acting Secretary of State to the Embassy in the Soviet Union, April 24, 1948, FRUS, 1948, 4: 834-835.

${ }^{14}$ The Ambassador to the Soviet Union to the Secretary of State, May 4, 1948, Ibid., 847-850. It is also worth nothing that when this cable was read to the Cabinet, it was done so with total secrecy.

${ }^{15}$ Memorandum by the Office of European Affairs to the Under Secretary of State, May 27, 1948, Ibid., 876-879.

${ }^{16}$ Carolyn Woods Eisenberg, Drawing the Line: The American Decision to Divide Germany, 19441949 (New York, 1996), pp. 404-406.

${ }^{17}$ Richard M. Freeland, The Truman Doctrine and the Origins of McCarthyism: Foreign Policy, Domestic Politics, and International Security, 1946-1948 (New York, 1972), p. 191. The term "National Military Establishment" was used in this same document p.359. According to Offner, the NME was "only an office," not a department, which the secretary of defense would preside over which would allow him to exercise "only general authority or control over the service departments and other defense establishment agencies." Another Such Victory, p. 191; also see: Harry S. Truman, Years of Trial and Hope, vol. 2 of Memoirs by Harry S. Truman (Garden City, 1956), p. 52.
} 
Establishment"-America's strategic planners-the highest priority because it recognized that the United States was "now engaged in the political phase of conflict with the Soviet-dominated world. Under these conditions, the security interests of the United States...may be advanced most effectively by preventing Soviet Communist expansion, which may take place either by political means or by direct military action."

The National Security Act of July 26, 1947 had created the National Security Council (NSC), a smaller War Council, the National Security Resources Board (NSRB), and the Central Intelligence Agency (CIA), all of which according to Marshall "gave the military excessive influence over foreign policy matters and infringed the constitutional authority of the president and secretary of state." Truman had made it clear at the first NSC meeting that the NSC was to be "his council." As Soviet-American tensions escalated in mid-1948, the president allowed the CIA to collect information from the Federal Bureau of Investigation as well as from the Atomic Energy Commission. ${ }^{19}$ It was this act, according to Michael J. Hogan, that "established the modern mechanism for the national security state. ${ }^{20}$ The acceleration of public fear that took place after mid1948 can be attributed to the change of attitude in the Truman administration. As the upcoming presidential election drew closer, Truman became more confident in his position as president and he began using anti-communist propaganda to his advantage. Clifford Clark, the president's special counsel and campaign strategist, advised the president that public support could be obtained by creating a "sense of crisis" and by emphasizing the

\footnotetext{
${ }^{18}$ Report by the SANACC Subcommittee for Rearmament, August 18, 1948, FRUS, 1949, vol. 1: National Security Affairs; Foreign Economic Policy: 265.

${ }^{19}$ Offner, Another Such Victory, pp. 191-192.

${ }^{20}$ Michael J. Hogan, A Cross of Iron (New York, 1998), p. 65.
} 
Soviet threat. ${ }^{21}$ What was going on had several unfortunate consequences. Richard M. Freeland writes that domestic anti-communist tactics were "inevitably generating a public atmosphere in which not only government employees, aliens, members of dissident organizations, but individuals in the general population, were made to feel that public opposition to the administration's policies would cause them to be branded communists.... 22 In autumn of 1947 , a loyalty program was formed to battle domestic communism, or any "security risk," a term loosely defined. A "security risk" was not only to encompass any employee associated with communist or other subversive organizations but also any employee associated with an individual so associated. ${ }^{23}$

The Cold War foreign policy "campaign" of the Truman administration "implanted the idea" in the minds of Americans "that the United States was imminently threatened by a massive, ideologically based assault" upon everything the nation valued. Freeland concludes that these actions "exaggerated representation of the dangers of international and domestic communism created the emotional and conceptual context within which Americans reacted to the Soviet explosion of the atomic bomb."24

As noted in the New Republic, this very tactic was at the time being used by Senator John Foster Dulles in his New York campaign. ${ }^{25}$ The scare tactic continued to be utilized after the election. Atomic scientists became particularly frightened. In response to the atomic explosion in Russia, Harold C. Urey of the Institute of Nuclear Studies at

\footnotetext{
${ }^{21}$ Offner, Another Such Victory, p. 238.

${ }^{22}$ Richard M. Freeland, The Truman Doctrine and the Origins of McCarthyism, p. 303.

${ }^{23}$ Ibid., pp. 236-237.

${ }^{24}$ Ibid., p. 11.

${ }^{25}$ Harold L. Ickes, "The Russian A-Bomb," New Republic, October 10, 1949, p. 17. According to the article, Senator Dulles "is trying to frighten the voters of New York into voting for him for Senator as against former Governor Lehman, by crying 'Communist."”
} 
the University of Chicago wrote for the Bulletin of Atomic Scientists that because scientists failed to convince Congress, the military and the public that there was no "secret," they were being accused of a desire to release supposed control of atomic information. This, in effect, meant they could become threats to national security. Urey continued that "every man in the Atomic Energy Commission and every scientist in a responsible position in the atomic project is hampered or even paralyzed in his work if he must permanently be on guard to defend himself against ridiculous accusations of real or imaginary violations of petty security regulations or against charges of having communist leanings. ${ }^{26}$ Frederick Seitz, Professor of Physics at the University of Illinois, agreed with Urey, but went further by stating that the United States would fall behind in the atomic race if the emphasis did not shift from "security" to "progress." It was better to focus attention on developing new knowledge, Seitz said, and "run the small danger that some of this information will be obtained by the Russians before they discover it themselves than that we strangle our efforts by the perverted guarding of secrets which will automatically become of small value to anyone, including ourselves, in due course of time."27 American atomic scientists feared for their jobs and personal security; each time that they stated a scientific claim that countered that of the U.S. Government, they felt they would be held liable for un-American activities.

The demonstrable confidence of the U.S. government in world affairs was, in part, attributed to the American atomic bomb monopoly. Secretary of Defense James Forrestal believed in December 1948, that the most important factor in deterring the

\footnotetext{
${ }^{26}$ Harold C. Urey, "Needed: Less Witch Hunting and More Work," Bulletin of Atomic Scientists 5 (October, 1949): 265.

${ }^{27}$ Frederick Seitz, "Danger Ahead," Bulletin of Atomic Scientists 5 (October, 1949): 266.
} 
Soviets "was the threat of the immediate retaliation of the atomic bomb." ${ }^{28}$ Senator Tom Connally (D-TX), speaking for the Joint Committee on Atomic Energy, stated that the "strong point about the atomic weapon is the fact that it creates mystery. The Russians do not know. They do not know the development. They do not know how many [bombs] we have, how we make them, or anything of the kind."29 David Holloway writes, in Stalin and the Bomb, that "Truman was increasingly convinced that the atomic bomb should indeed provide the central element in strategic policy. In July 1949, he told his advisors that 'I am of the opinion we'll never obtain international control. Since we can't obtain international control, we must be strongest in atomic weapons.",30 Although the administration knew that the United States would not hold the monopoly indefinitely, officials were self-assured enough to rely on it as the "central core" in American "offensive capabilities." Until the Soviets attained nuclear power, it was the intention of the policy makers in regard to atomic weapons:

(a) To obstruct Soviet progress as much as possible, both as to the time of securing the first bomb and the subsequent rate of production.

(b) To improve the position of the U.S. as much as possible vis-à-vis Russian position.

(c) To reduce vulnerability of productive capacity and stockpiles to destruction by Russian action.

(d) To improve the means of delivering atomic bombs against Soviet targets in the event of war.

(e) To have our policy in this field consistent with our general foreign policy. ${ }^{31}$

\footnotetext{
${ }^{28}$ Walter Millis, ed., The Forrestal Diaries (New York, 1951), p. 538. James Forrestal was already mentally preparing for war with the Soviet Union in late 1948. His largest concern about defense was the ability of the United States to "deliver a powerful [atomic] blow at the Russian's capacity to make war."

${ }^{29}$ U.S. Congress, Hearings Before the Joint Committee on Atomic Energy, $81^{\text {st }}$ Congress, $1^{\text {st }}$ sess., February 2, 1949 (Washington D.C., 1949), p. 11.

${ }^{30}$ David Holloway, Stalin and the Bomb (New Haven and London, 1994), p. 229.

${ }^{31}$ Notes on a Meeting at Princeton, New Jersey, January 24-25, 1949, FRUS, 1949, 1: 425-427.
} 
Just two weeks before the Soviet atomic detonation, policy makers were assessing the political implications of atomic capabilities by the USSR. In a report by the Department of State Policy Planning Staff, it was concluded that it was essential for the security of the United States that a method be obtained to detect a Soviet atomic detonation. Because the United States was the sole possessor of atomic technology, the administration felt that world collaboration was more likely to be successful. Policy makers also believed atomic detection was necessary because the administration would be able to anticipate changes in Soviet foreign policy that might result from its possession of atomic weapons. Furthermore, the Soviet possession of atomic bombs would require the United States to reevaluate its foreign policies and defense tactics. ${ }^{32}$ But intelligence agencies assured the Truman administration that Soviet atomic capabilities were at least five years away, however; that was not to be the case.

In the Soviet Union on August 29, 1949, moments after their successful atomic test, Lavrentii Pavlovich Beria the Chair on the Special Committee on the Atomic Bomb, began asking if the explosion was comparable to the American one. "We didn't screw it up? Kurchatov [scientific director of the nuclear project] isn't pulling our leg, is he?" Beria continued to ask in excitement to those that attended the Bikini Atoll test. Beria and Stalin were "fully aware of the great political and military significance of the new weapon.... [Because] the future role of the USSR in the world would depend on the terrifying yield of its nuclear arsenals.",33

\footnotetext{
${ }^{32}$ Report by the Policy Planning Staff, August 16, 1949, FRUS, 1949, 1: 514-515.

${ }^{33}$ Vladislav Zubok and Constantine Pleshakov, Inside the Kremlin's Cold War: From Stalin to Khrushchev (Cambridge, 1996), p. 151. The Soviet detonation of the atomic bomb occurred August
} 
Although the United States had already begun gathering intelligence about the Soviet nuclear project, the information was limited and thus contributed to the underestimation of Soviet scientific capabilities. ${ }^{34}$ The U.S. government, according to John Lewis Gaddis, "had fallen into the bad habit of pushing their range of estimates [for the Soviet atomic bomb] forward each year." 35 In War or Peace, John Foster Dulles recalled that in the spring of 1949 , U.S. top officials "were then convinced that it would probably be five years or more before the Russians would be able to make atomic bombs." ${ }^{36}$ According to Dean Acheson, the "Russians had anticipated all [American] predictions by at least two years." ${ }^{37}$ Life Magazine attributed the Soviet detonation to the lack of confidence the United States had in Russian science and industry. ${ }^{38}$ In his Memoirs, Truman downplayed the Soviet detonation by writing that the "United States was not unprepared for the Russian atomic explosion;" however, Truman did note that the explosion was not expected until at least 1952. ${ }^{39}$ In Man of the People, Alonzo L. Hamby quoted Truman as saying only about five months earlier that "our best estimate is that we have several years in which we can count on a breathing spell [until the Soviets develop the bomb]." ${ }^{40}$ According to Arnold A. Offner, Truman's immediate reaction was disbelief; then he attributed its success to the German scientists working for the Russians. Only after the Atomic Energy Commission (AEC) verified the detonation,

29, 1945. The United States invited Soviet scientists to attend the first public demonstration of atomic power at Bikini atoll, July 1, 1946. This was both a demonstration of American power as well as an act of goodwill.

${ }^{34}$ Ibid., p. 220.

${ }^{35}$ John Lewis Gaddis, We Now Know: Rethinking Cold War History (New York, 1997), p. 100.

${ }^{36}$ John Foster Dulles, War or Peace (New York, 1950), p. 111.

${ }^{37}$ Dean Acheson, Present at the Creation: My Years in the State Department (New York, 1969), p. 320.

38 "The U.S.S.R. Has A Topflight Science Team," Life, October 3, 1949, p. 20.

${ }^{39}$ Truman, Years of Trial and Hope, pp. 306-307.

${ }^{40}$ Hamby, Man of the People, p. 524. 
did the president "insist that the agency chair, David Lilienthal, and the detection committee sign a statement that they believed that the Russians had detonated a bomb." ${ }^{41}$ Even so, continues Hamby, Truman was still calling the Soviet atomic bomb a "phony" as late as March $1952 .{ }^{42}$

Dulles, a Republican and future secretary of state noted the Soviet bomb changed the strategic position of world power to their advantage because the American economy was more vulnerable to a nuclear attack. Dulles also stressed the importance of looking to the future to "foresee that the possession of atomic weapons greatly increases the area within which the Soviet Communist leaders and the leaders of local Communist parties can exert terroristic threats." The Soviet "scope" had been widened, therefore, greatly increasing the "likelihood of winning over governments and peoples of countries, which are highly vulnerable to atomic attack by Soviet Russia."43 Periodicals verified government fears by continuing to stress the vulnerability of the United States to Soviet aggression. U.S. News and World Report portrayed the Soviet Air Force as larger and stronger than that of the United States, informing readers that it was the strongest in the world. $^{44}$

After several days of hesitation, on September 23, 1949, President Truman announced to the world that an atomic explosion had occurred in the Soviet Union and the U.S.S.R. now had atomic capabilities. What the president did not say, it is important to note, is the Soviets detonated an atomic bomb. Although the administration reacted

\footnotetext{
${ }^{41}$ Offner, Another Such Victory, p. 359.

${ }^{42}$ Hamby, Man of the People, p. 525.

${ }^{43}$ Dulles, War or Peace, p. 152.

44 "Truth About Soviet Air Force: Now the Biggest in the World," U.S. News and World Report, October 21, 1949, pp. 11-13.
} 
calmly before the American public, it was painfully clear to Truman and his advisors that the Soviet detonation of an atomic device changed the world. ${ }^{45}$ It was at this time, wrote Acheson in Present at the Creation, that the administration began to rely on the State Department "as never before for new policies to meet the new dangers." 46 The American press commended the administration for disclosing the information before the Soviets had the opportunity to make their own announcement. ${ }^{47}$ President Truman feared that the announcement would have a tremendous effect on Western Europewhose leaders feared another war-as well as the United States, but it was the administration that was most agitated. The United States would no longer be able to deter "Soviet adventurism" with an atomic monopoly. Soviet atomic capability fed the fears of the Truman administration with the belief that the next world war would be fought with atomic explosives against highly populated areas with massive production facilities. $^{48}$ As Melvyn P. Leffler notes, “the nation's entire foreign policy posture required reappraisal."49

A Soviet atomic explosion, although eventually expected, was not expected by the Truman administration as early as fall 1949. In his August 31 diary entry, Truman's

\footnotetext{
${ }^{45}$ LaFeber, America, Russia, and the Cold War, 1945-1990, pp. 84-85.

${ }^{46}$ Acheson, Present at the Creation, p. 345. Acheson concluded that the State Department was the president's "chief instrument" for developing foreign policy and would continue to be for the next twenty years.

47 "National Affairs," Time, October 3, 1949, p. 7. The article detailed that the question of whether the U.S. government should disclose the information was considered because it would make the world aware of its atomic diction system, and it was also considered that it would be best if the Russians did not know that that the United States was aware of their atomic detonation. But, "no one wanted to let the Russians make a triumphant announcement at a moment of their choosing, when the news might become a massive propaganda coup."

${ }^{48}$ Aaron L. Friedberg, In the Shadow of the Garrison State: America's Anti-Statism and its Cold War Grand Strategy (Princeton, 2000), p. 38.

${ }^{49}$ Melvyn P. Leffler, A Preponderance of Power: National Security, the Truman Administration, and the Cold War (Stanford, 1992), pp. 326-327.
} 
assistant press secretary Eben A. Ayers wrote the president commented in their morning staff meeting that "we are now nearer to war than we have been at any time." government officials were clearly startled by the event; however, they quickly regained composure. $^{51}$ Although the administration's confidence was briefly shattered, the Russian atomic detonation actually helped to further Truman's foreign and domestic policies. Because of the Soviet atomic bomb, Truman and his advisors were better able to implement and enforce more rigid national security procedures. It was as a direct consequence of Soviet actions that the Truman administration was able to go forward with the development of the hydrogen bomb. ${ }^{52}$

Immediately the press seized the moment to politicize the event. The New Republic compared the American reaction to the Soviet detonation with the Soviet reaction to the American atomic bomb. Both publicly shrugged their shoulders, but privately undertook new actions that affected both government and country. The New Republic described the international mood in reaction to the Soviet detonation as hysterical and demoralizing, which it labeled dangerous. The administration said that a Soviet detonation was fully anticipated, and that "its significance was discounted long ago.... Nothing is altered...our strategy, military, economic and political, is as sound as ever and will continue unchanged." In response, the New Republic retorted that the content, although intending to calm Americans, was "nonsense." If Americans were not surprised or scared, the New Republic observed, it was because they have conditioned

\footnotetext{
${ }^{50}$ Robert H. Ferrell, ed., Truman in the White House: The Diary of Eben A. Ayers (Columbia, 1991), p. 326. Ayers spoke with the president almost everyday, attended most presidential morning meetings, and worked closely with Truman's principal advisors.

${ }^{51}$ Presidential advisors assured the president that the Soviets would not be capable of producing an atomic bomb until 1952 at the earliest.

${ }^{52}$ The decision to build the hydrogen bomb will be discussed at length in Chapter 3.
} 
themselves, "as a kind of self protection, to insensibility to the terrifying prospects and almost unsolvable problems" that they now face. ${ }^{53}$ Former New Deal Brains Truster Raymond Moley's perspective, printed in Newsweek, was that a false security was created because of the past complacency of both the American public and government officials, and now, this attitude was unacceptable. Furthermore, the Soviet atomic detonation was a "second call" to the United States, and "when and if the third call comes, it will be too late to think." ${ }^{, 4}$ Therefore, the press disregarded the president's pronouncement of governmental calm, and instead helped to create a hysteria it had just declared as dangerous. But, in reality, it was the administration that had been using the press to make the most of this crisis. Richard M. Freeland argues throughout his book that the Truman administration exaggerated the communist threat in order to achieve international and domestic objectives. ${ }^{55}$ As John Fousek declares,

In the official discourse of the Truman administration, and in much of the commercial mass media, freedom was equated with capitalism, and communism was deemed a new slavery. In 1947 and 1948, policy makers and opinion leaders gradually came to speak of "a democratic world" or "a free world" when discussing either the American-led block or the ultimate aim of U.S. leadership. ${ }^{56}$

Within days of the president's announcement, U.S. News and World Report told Americans that now the Russians had the atom, the United States had fallen two years behind in the atomic arms race. With pictures of a troubled-looking Truman and a smiling Stalin, the article continued to detail possible Soviet means of delivering an atomic bomb, and noted "suicide planes were believed to be the only feasible means of

\footnotetext{
53 “The Soviet Bomb," New Republic, October 3, 1949, p. 5.

${ }^{54}$ Raymond Moley, "An Atomic Balance of Power," Newsweek, October 10, 1949, p. 96.

${ }^{55}$ Freeland, The Truman Doctrine and the Origins of McCarthyism.

${ }^{56}$ John Fousek, To Lead the Free World: American nationalism and the Cultural Roots of the Cold War (Chapel Hill, 2000), p. 131.
} 
delivering Russian bombs to targets in the U.S." ${ }^{\text {57 }}$ An editorial in Life Magazine emphasized that the Soviet Union was using propaganda to create the impression that the Western powers were instigating a war situation. ${ }^{58}$ In an informal interview with Dr. Ralph E. Lapp, the former executive director of the Interdepartmental Committee on Atomic Energy in the National Military Establishment, U.S. News and World Report asked about the importance of the Russian atomic bomb and Russia's ability to massproduce nuclear weapons. Lapp estimated that the Soviets should be able to build about one hundred bombs within the course of two years; consequently, the United States was now definitely in an armaments race. The fact that the Russians did not announce or confirm their detonation, Lapp commented, was because they wanted to get the United States in a "nicely confused mess," purposely creating "pandemonium.",59

To a large effect that effort worked. Coupled with the fall of China to communism, it gave the Truman administration a direction it otherwise lacked. The Truman loyalty program was put into high gear, which eventually led to the rise and acceptance of McCarthyism in early 1950.

With a smiling Stalin on the Cover of Newsweek, a banner across the top read "Atom War, Cold War, or Peace Through Fear?" Under Stalin's picture were the words: "Stalin: The Man With the Bomb." In one of several articles devoted to the Soviet detonation, Newsweek gathered information from its overseas offices in Europe and Great Britain, and concluded that the "public has become inured to postwar scares, and

\footnotetext{
57 "What to do About A-Bomb Now that Russia Has It," U.S. News and World Report, September 30, 1949, pp. 13-15.

58 "Toward a Climax," Life, October 3, 1949, p. 22.

59 "Critical Time for A-Bomb World is Two Years Hence: An Interview with Dr. R.E. Lapp," U.S. News and World Report, September 30, 1949, pp. 16-19.
} 
there is a general feeling that Western Europe, with the United States behind it, has no need to get panicky over the Russians." The article also contained a blurb that the "most frightfully explosive force ever discovered was in the hands of the totalitarians," and concluded that mankind was witnessing a turning point in history. ${ }^{60}$

Time Magazine projected the extent of the nation's surprise by stating that although the news was inevitable, it "hit the nation with the jarring impact of a fear suddenly become fact." Having compared the event to a thunderclap, Time continued, "The comfortable feeling of the U.S. monopoly was gone forever. The fact was too big and too brutally simple for quick digestion. What had been a threat for some time in the future, hard to visualize, easy to forget, had become a threat for today, to be lived with.",61 Robert J. Donovan, former Army Sergeant reemployed at the New York Herald-Tribune and later Truman's biographer, "recalled that the public reaction to Truman's announcement [was] 'a quiet sense of dismay and dread'—not hysteria, but a realization that the USSR had neutralized America's biggest military edge and that a civilian-destroying atomic war was now possible." ${ }^{\circ 2}$

In a direct appeal to women readers, Life Magazine's explanation came complete with vivid pictures, which lightly described wind currents and radioactivity as well as the instruments used in such detection. ${ }^{63}$ Rather than long scientifically detailed descriptions of current events, Life utilized photographs to appeal to women. The images the magazine chose were very powerful. In a two-page report on Russia's ability to deliver the atomic bomb, there appear only three small paragraphs and six large

\footnotetext{
60 "The Bomb: The Story Explodes Around the World," Newsweek, October 3, 1949, p. 17.

61 "National Affairs," Time, October 3, 1949, p. 7.

${ }^{62}$ Hamby, Man of the People, p. 525.

63 "How was the Atomic Explosion Detected?" Life, October 3, 1949, pp. 18-19.
} 
pictures; however, it is the pictures that readers remember, not the accompanying article. Four pictures show the ways that Russia can deliver the bomb: an airplane, a submarine, a freighter, and a truck. Also accompanying the article was mention of the New York bomb explosion of 1920, put into the context of current events. ${ }^{64}$ The caption below the blast picture read: "In 1920 Reds Exploded Bomb In Wall Street, Killed 30, Wounded Hundreds." As noticed by James Aronson, this article, and especially this picture, added to the public hysteria about the Soviet bomb. Because "few readers would recall the incident, and fewer still would check the accuracy of the caption,"-Aronson noted that the explosion was not attributed to any group, let alone Reds-the editors could knowingly print false information about the incident to "bridge the 29-year gap from dynamite bomb to atomic bomb." The picture may have been misrepresented. It was, however, a strong visual image of what might happen. ${ }^{65}$

The press took the news of Soviet atomic capability and fabricated catastrophic scenarios about the horrors of atomic war. Periodicals began to devise a new war game with Europe as the primary theater. U.S. News and World Report concocted a chess-like match for the reader with each side making its atomic play. ${ }^{66}$ In the same issue, there was an examination of city layouts. With pictures of major, vulnerable cities, the article devised a new plan to spread out the population because dense cities of over 100,000 people were prime targets for Soviet atomic bombs. Another option outlined was to move government buildings and factories underground. ${ }^{67}$ In an earlier issue, U.S. News and World Report had printed diagrams of future city development alternatives, and also

\footnotetext{
64 “Can Russia Deliver the Bomb?" Life, October 10, 1949, pp. 44-45.

${ }^{65}$ James Aronson, The Press and the Cold War, p. 57.

66 "Atom Threat: Boost for Army," U.S. News and World Report, October 7, 1949, pp. 20-21.

67 “' 'Fringe' Cities: Answer to A-Bomb,” U.S. News and World Report, October 7, 1949, pp. 18-19.
} 
listed ninety-two cities that were vulnerable to atomic attacks by the Soviet Union. These cities were vulnerable, U.S. News and World Report continued, if the Russians deployed one-way suicide bombers, an idea that was becoming not only popular, but also convincing. ${ }^{68}$

Although Time called the Soviet detonation "The Thunderclap," it relayed that "by and large, the U.S. accepted the fact with grim concern, but no panic." Yet, it pointed out that the government officials were shaken even as they put forward several proposals to enhance the nation's security. For example, Senator Robert Taft (R-OH) "renewed the argument that the U.S. take strategically placed Spain into the community of nations fighting communism." There was also a concern that government agencies should move out of Washington. Some men joked to one another that they should get out their old uniforms or moving into the hills. ${ }^{69}$ There was also mention of developing bomb shelters. The New Republic also emphasized that Truman administration was visibly rattled by the event. The Chairman of the Atomic Energy Commission David E. Lilienthal spoke of an atomic arms race. The periodical charged Representative Harold H. Velde (R-IL), a member of the House Committee on Un-American Activities (HUAC), with contributing to the public fear by his "toad to the witches brew of hysteria by charging intemperately that 'The Russians gained two years in producing the atomic bomb...because the federal government has been infiltrated by a network of spies."70 Whether or not the allegation was factually supportable, it is clear that such behavior by the press helped to instigate an alarmed reaction by the public. Harold L. Ickes wrote in

\footnotetext{
68 "What to do About the A-Bomb," U.S. News and World Report, September 7, 1949, pp.14-17.

69 "National Affairs," Time, October 10, 1949, p. 7.

${ }^{70}$ Ickes, "The Russian A-Bomb." Ironically, this statement was made before Alger Hiss was charged with treason.
} 
New Republic that the poise of the press "was amply demonstrated by a geyser like eruption in the newspapers and over the air of uncountable millions of words. Newspapers and commentators excitedly shrilled news that should not have been startling, since the event had been previously predicted."71

Scientists reacted just as strongly to the news of the Soviet atomic bomb as did the press and the government. "Did the Soviet Bomb Come Sooner Than Expected," asked the Bulletin of Atomic Scientists, testing the accuracy of atomic scientists in their estimates of the production of a Soviet bomb. Unburdened by political concerns, the scientific community had accurately anticipated the development of a Soviet atomic bomb. Leo Szilard had predicted in October 1945 that although it was not likely, it was possible for another country to obtain an atomic bomb within two and one-half years. In a letter to the Secretary of War Henry Stimson in June 1945, the Franck Committee wrote that the Russians understood the implications and facts of nuclear power and it would only be three to four years before another country caught up to the United States. Frederick Seitz and Hans Bethe wrote in 1946 that it would take a foreign country no more than five years to produce an atomic bomb. Harold C. Urey agreed with the fiveyear estimate. Harrison Brown warned in 1946, "All of us must recognize that in another three years the United States of America may not stand alone as a possessor of atomic bombs." Testifying before a Senate committee on December 3, 1945, Vannevar Bush declared that if the Soviet Union "threw her full weight into it," then it could have fully operational atomic plants within four or five years. By publishing three pages of past statements, the Bulletin of Atomic Scientists was easily able to prove its point that those

\footnotetext{
${ }^{71}$ Ibid.
} 
in the scientific community had informed the government that the Soviet Union had the will and scientific knowledge to produce an atomic bomb in a relatively short time. ${ }^{72}$ Unfortunately, the Truman administration turned a deaf ear to their warnings and chose instead to make its own predictions.

Since the bombing of Hiroshima and Nagasaki by the United States, the Soviet Union had pushed for international atomic control. This would allow, the Russians claimed, for information to be shared and put to more productive uses. But the atomic monopoly was not to be given up so easily by the United States; not only did it imply international superiority; it was also a means of deterring the Soviet Union. Publicly, the U.S. government made an attempt to devise a means of international control, but privately, it was not a consideration of the administration because international control of atomic weapons would take away this authority from the United States.

As far as Truman and his principal advisors were concerned, the atomic bomb was the ultimate weapon, or what Bernard Baruch called "the winning weapon."73

Truman's allusion to Stalin about the American atomic bomb at Potsdam had only increased Stalin's resolve to obtain nuclear technology. The Russians already had begun an atomic bomb project of their own, and as noted by Elie Able, the biographer of $\mathrm{W}$.

\footnotetext{
72 "Did the Soviet Atomic Bomb Come Sooner than Expected?" Bulletin of Atomic Scientists 5 (October, 1949): 262-264.

${ }^{73}$ Gregg Herken, The Winning Weapon: The Atomic Bomb in the Cold War, 1945-1950 (New York, 1980), pp. 153-172. Bernard Baruch was the head of the US delegation to the UN Atomic Energy Commission. Significantly, Baruch also helped to redraft the Acheson-Lilienthal Plan for international atomic control. The Baruch Plan focused on punishment of violators rather than international cooperation, and according to Herken, "needlessly provoked the Russians," p. 152.
} 
Averell Harriman, in Special Envoy to Churchill and Stalin, soon after Truman's remark about the bomb, "Stalin sent back immediate orders to accelerate the program.", 74

Harriman later recalled that Molotov clarified why Stalin was not surprised to hear about the new weapon. After Potsdam, Harriman and Molotov were talking about "Japan and the bomb, when Molotov looked at me with something like a smirk on his face and said, 'You Americans can keep a secret when you want to.' The way he put it convinced me that it was no secret at all." ${ }^{, 75}$ On November 6, 1947, Soviet Minister of Foreign Affairs Vyacheslav M. Molotov delivered a speech that attacked American imperialism, declaring, "In expansionist circles of the U.S.A. a new, peculiar sort of illusion is widespread - faith is placed in the secret of the atomic bomb, although this secret has long ceased to exist." Walter Millis, editor of The Forrestal Diaries, remarked that this was the "first authoritative indication that the Western monopoly of the weapon might be at an end." ${ }^{, 76}$ Scientists not connected with America's atomic bomb project regarded the comment as a bluff and determined that the Soviet scientists were not capable of producing an atomic weapon earlier than $1952 .{ }^{77}$

Until mid-1948, President Truman and his advisors were ready and willing to take a more assertive position with the Soviets; however, before then nothing warranted a dramatic change in American foreign policy. Through the use of fear, the administration was able to successfully use anti-communist rhetoric to further its domestic and foreign

\footnotetext{
${ }^{74}$ W. Averell Harriman and Elie Abel, Special Envoy to Churchill and Stalin, 1941-1946 (New York, 1975), p. 491.

${ }^{75}$ Ibid.

${ }^{76}$ Millis, ed., The Forrestal Diaries, p. 340n; Charles E. Bohlen, Witness to History, 1929-1969 (New York, 1973), p. 237 fn.; "The Soviet Announcement," Bulletin of Atomic Scientists 5 (October 1949): 261

77 "The Soviet Announcement," Bulletin of Atomic Scientists 5 (October 1949): 261.
} 
aims. The press sensationalized the threat of a third world war by utilizing the rhetoric of the administration. This hysteria created by the press only furthered the agenda of the U.S. government. When Public Opinion Quarterly asked if the United States was too soft or too firm in its policy toward Russia, seventy-three percent of those asked replied "too soft."78 As noted earlier, almost three-quarters of all Americans believed that World War III was inevitable. These public beliefs allowed for popular support of increased hostility toward the Soviet Union. But ultimately, it was the Soviet Union that gave the Truman administration the outlet it was looking for when it detonated an atomic bomb. In addition, the Soviet detonation happened barely one month before the fall of Nationalist China. Although these two events were seen to have shifted the balance of power - as far as the administration was concerned-in the favor of the Soviet Union, it strengthened the resolve of U.S. policy makers and directly initiated the development of the hydrogen bomb. As Walter LaFeber writes, for "American policy makers, the struggle for Europe had reopened.",79

As the administration continued to identify supporters of Cold War foreign policy with "loyalty and patriotism" and label opponents as "subversives and communists," American fears were further escalated. By using anti-communism as a campaign to further their agenda, policy makers made it difficult for themselves as well as the public to assess the reality of the Soviet threat. Even the president acknowledged, according to Freeland, that the "anti-communist sentiment in the country had reached excessive levels and needed to be damped down." It appeared to the American public that the "Soviet

\footnotetext{
78 “The Quarter's Polls," Public Opinion Quarterly 13 (Spring 1949): 146.

${ }^{79}$ LaFeber, America, Russia and the Cold War, 1945-1990, p. 85.
} 
Threat" was everywhere: not only in Europe, but also infiltrating the United States. To this end, continues Freeland, "this exaggerated representation of the dangers of international and domestic communism" created the "emotional and conceptual context" within which Americans reacted to national and international events. ${ }^{80}$

Soon the danger that Americans would be focused on would not only be domestic but global in scope. The administration would counter-threat the Soviets by initiating the development of the hydrogen bomb - a weapon so powerful that scientists predicted the extinction of man was within the near future. Although a climate of fear was circulating within the American public because of escalated international tensions, the decision to pursue the H-Bomb was felt as a direct threat to civilization. The fact that the hydrogen bomb only had one use — of devastation - did not aid in the acceptance of the Truman administration's decision. The climate of fear was going to be escalated even further.

\footnotetext{
${ }^{80}$ Freeland, The Truman Doctrine and McCarthyism, pp. 10-11.
} 


\section{Chapter 3}

\section{Truman's Hydrogen Bomb Decision}

Did the United States have the capability to retaliate if the Russians decided to attack? This was the question of the utmost concern to U.S. policy makers in 1949. Until the Soviet Union detonated an atomic device, the atomic bomb had been the central core-and winning weapon- of the American arsenal. It was relied upon to provide an immediate means of counterattack and retaliation because it would accomplish in a short amount of time what conventional weapons took much longer to do. According to the National Security Council (NSC), the atomic bomb was "neither [an] absolute or ordinary" weapon, but a "unique weapon" because, "at minimum," it would provide the paralyzing impact "to furnish the time required to mount an offensive combined with more conventional means of warfare" in the case of an outbreak of war. ${ }^{1}$ Since the bombing of Hiroshima and Nagasaki, the American public has feared as well as been awed by the destructiveness of the atomic bomb.

With the Soviet acquisition of atomic power the Truman administration had the ammunition it needed to intensify an already aggressive foreign policy. The direct result was the hydrogen bomb project. This not only increased the military budget, it also helped to unify policy makers. However, the H-bomb decision divided scientists and created hysteria among the American public. Physicists helped to create national alarm

\footnotetext{
${ }^{1}$ A Report to the President by the Special Committee of the National Security Council on Atomic Energy Policy with Respect to the United Kingdom and Canada, March 2, 1949, Foreign Relations of the United States, 1949, vol. 1: National Security Affairs; Foreign Economic Policy: 449 (hereafter, FRUS). It is also important to note that the atomic bomb was financed by the AEC, not the military; therefore, it was more economic to produce bombs than to increase traditional means of warfare.
} 
because they understood the destructive potential of thermonuclear power. Americans, on the other hand, were scared because they did not know what implications the hydrogen bomb would have on the future. But with regularity, the press informed the public of the Super bomb's potential. Unlike the atomic bomb, scientists and the American public were not unified in their view of the hydrogen bomb. Truman's decision to build the hydrogen bomb in a time of peace and its implications to both scientists and the public is the subject of this chapter.

The reality of the Soviet atomic bomb was "shocking," writes Melvyn P. Leffler in $A$ Preponderance of Power, because of its psychological and political implications. ${ }^{2}$ The psychological impact did not only affect the American public; it affected government officials more so. Atomic weapons had been central to war plans of the United States, Soviet deterrence, and American strategic superiority; now those plans had to be reevaluated. The United States needed new and stronger measures in addition to the atomic bomb to make its defense and the deterrence of the Soviet Union credible. ${ }^{3}$ Although this event temporarily created a chaotic atmosphere in the State Department and the White House, it was ultimately used to further the foreign and domestic policies of the Truman administration. Rather than consult his atomic scientists for advice, the president chose instead to listen to his political advisors and military planners. ${ }^{4}$

\footnotetext{
${ }^{2}$ Melvyn P. Leffler, A Preponderance of Power: National Security, The Truman Administration, and The Cold War (Stanford, 1992), p. 326.

${ }^{3}$ For a discourse on credibility see: Robert J. McMahon, "Credibility and World Power: Exploring the Psychological Dimensions in Postwar American Diplomacy," Diplomatic History 15 (Fall 1991): 455-471.

${ }^{4}$ Arnold A. Offner, Another Such Victory: President Truman and The Cold War, 1945-1953 (Stanford, 2002), p. 360; Although some atomic scientists were for the development of the hydrogen bomb, many were against it for technical as well as for moral reasons. These same men also noted that a hydrogen bomb project would only initiate an armaments race with the Soviets. Also see: Richard Rho-
} 
Truman was never fully exposed to arguments against the use and development of the atomic bomb; however, he did make his opinion clear concerning its future necessity in international diplomacy. ${ }^{5}$ Shortly after the war, the Interim Committee and its Scientific Panel were disbanded by Truman, thus severing his best source of information and advice on nuclear weapons. According to Offner, "as late as fall 1949 he seemed oblivious of work being done at Los Alamos." Instead, the president relied on the military for advice on atomic weapons. ${ }^{6}$ But the men that Truman relied upon most were not all together ethical in giving their advice. They politicized the process. It was concluded in the Harmon Report of May 1949 by the JCS that the use of atomic weapons on the Soviet Union would be fruitless because it was unlikely that it would cause the roots of communism to diminish or that the use of atomic bombs would cause the Russians to surrender. Furthermore, the report stressed the results of an atomic attack might produce "psychological and retaliatory reactions detrimental to the achievement of Allied war objectives." ${ }^{7}$ Because these conclusions disappointed the JCS, they were hidden from the president, despite several requests to see the report. If the president had access to another view on atomic diplomacy, it was possible, the JCS feared, that Truman would not adhere to the firm stand he had been advised to take with the Soviet Union.

Because the president had removed himself from research developments, he was unaware that physicists had been exploring the idea of a hydrogen bomb since the Manhat-

des, The Making of the Atomic Bomb (New York, 1986), pp. 768-769; Leffler, A Preponderance of Power, p. 328.

${ }^{5}$ Richard Rhodes, Dark Sun: The Making of the Hydrogen Bomb (New York, 1995), p. 363. Truman had announced at a meeting in mid-July 1949 that he was "of the opinion that we'll never obtain international control [of atomic energy]," and "since we cannot obtain international control, we must be the strongest in atomic weapons." This pronunciation "foreordained" that the United States would respond to the lack on international diplomacy with the increase in atomic bomb manufacture.

${ }^{6}$ Offner, Another Such Victory, p. 359.

${ }^{7}$ Ibid. Lieutenant General Hubert R. Harmon headed the case study by the JCS. 
$\tan$ Project. In 1943, Edward Teller proposed working on the hydrogen bomb while at Los Alamos. At the time, however, the scientists were unable to get past the technicalities. But even then, the development of a hydrogen bomb was frightening to most of the scientists. Its power was seen as absolute and unnecessarily destructive. ${ }^{8}$ In August 1948, Leonard Engel wrote for The Nation that the "atomic superbomb would be a thousand times more powerful than the 'ordinary' uranium or plutonium bomb."9

"As soon as news of the Soviet atomic explosion became known," writes Leffler, "champions of thermonuclear weapons stepped up their demands for money and personnel." Congress had already approved the Presidential defense budget, which had disappointed Secretary of State Acheson and his department. But on October 10, 1949, President Truman approved an acceleration of the atomic energy program, which expanded the production of uranium and plutonium. The Joint Chiefs of Staff (JCS) "reiterated the cost effectiveness of the atomic weapons," and justified the need of the United States to have a larger stockpile of atomic weapons to attack Soviet atomic targets as well as to "fulfill the strategic undertakings already enumerated in U.S. war plans." This decision set the tone for Truman's support of the hydrogen bomb. ${ }^{10}$

Truman's administration was not unanimous in the decision to accelerate thermonuclear experimentation. A member of the General Advisory Committee, James Bryant Conant, had moral reasons for not believing in the acceleration of the hydrogen bomb project. Although he believed and accepted the necessity for chemical and atomic warfare during war, he did not believe in the advancement of destructive weapons during

\footnotetext{
${ }^{8}$ Although many of the atomic scientists were against the building of a hydrogen bomb, several of the leading physicists were interested in the project.

${ }^{9}$ Leonard Engel, "Science Notebook," The Nation, August 21, 1948, p. 231.

${ }^{10}$ Leffler, A Preponderance of Power, p. 327.
} 
peace. David Lilienthal, the AEC Chairman, was also against the Super bomb, and as Rhodes writes, Lilienthal found "nuclear weapons obscene." Scientists published an article in which prominent scientists voiced their views on the future of American security as a result of the Soviet detonation. Sir John Boyd Orr, former Director General of the Agricultural Organization and Economic Council, stated that no government would willingly go to war; therefore, 'the danger is that in the present cold war, the armaments race and the propaganda stirring up fear and hatred will create an inflammatory political atmosphere in which some otherwise trifling incident will flare into a world war.",12

Truman's advisors began to evolve into a group of men more determined and focused on the containment of the Soviet Union than ever before. The biggest and most significant change was the replacement of the head of the State Department's Policy Planning Staff, George Kennan, with Paul Nitze. According to Michael J. Hogan, "Every bone in Nitze's body ached with suspicion of the Soviet Union." He was a perfect match for the State Department. With Nitze at his side, Acheson felt he would be better able to fight the economizers "with their old ways of thinking," as well as the president who was trying to balance welfare with warfare. ${ }^{13}$ According to Acheson, the United States needed to stay ahead in the atomic game.

\footnotetext{
${ }^{11}$ Rhodes, Dark Sun, p. 386.

12 "More Scientist Comment on the Soviet Bomb," The Bulletin of Atomic Scientists 5 (November 1949): 323.

${ }^{13}$ Michael J. Hogan, A Cross of Iron: Harry S. Truman and The Origins of the National Security State, 1945-1954 (New York, 1998), pp. 292-294; George Kennan, Memoirs, 1925-1950 (Boston and Toronto, 1967), pp. 472-474. Kennan in late 1949 believed that a nuclear war with the Soviet Union would be non-productive, and was opposed to the idea. Instead, he proposed economic means to contain the Soviets. Needless to say, he soon lost favor and left government office completely. Another significant change in the administration was the resignation of Edwin Nourse, Chairman of the Coun-
} 
With the Soviet atomic detonation, Acheson and Nitze organized a committee to reevaluate the national security requirements of the United States. Headed by Nitze, it was composed of "like-minded officials including supporters of the State and Defense departments but none of the economizers who had thrown a wrench into so many previous plans." The result of their study was NSC-68.

Unlike the prior NSC document $20 / 4,{ }^{14}$ NSC-68 contained a greater sense of urgency to the Soviet problem. The document separated the world into two separate spheres of influence--the free and the slaves. Although, it was stated that it was clear that the Soviet Union had no intentions of provoking a war with the United States, NSC-68 declared that it was the intention of the Soviet Union to "impose absolute authority" upon the world, but placed the entire world in the realm of American national security. Therefore, anything that was done anywhere was a direct threat to the vital interests of the United States. According to George Kennan and Charles E. Bohlen, the implementation of NSC-68 would make "American policies too rigid, simple and militaristic." However, this was just the direction in which the State Department wanted to go. ${ }^{15}$ Ultimately, Acheson's counsel outweighed the decisions of Kennan and Bohlen. Historian John Lewis Gaddis notes that the important thing, Acheson thought, was "Moscow's $c a$ -

cil of Economic Advisors, who was replaced by Leon Keyserling, who also would aid the NSC. Also Robert Lovett took over as under secretary of defense.

${ }^{14}$ NSC 20/4 was a "middle-ground" paper drafted in 1948 that stated that the Soviet threat was "primarily ideological, economic, and political, but not military." Accordingly, the United States was to maintain a "level of preparedness that could be sustained over the long term and would be sufficient to meet 'immediate military commitments," Hogan, A Cross of Iron, pp. 165, 294. According to Leffler, NSC 20/4 set the official tone of President Truman's beliefs on the global containment of communism. It "reaffirmed the expansionist goals he had been pursuing," Leffler, A Preponderance of Power, pp. 264-265.

${ }^{15}$ Charles E. Bohlen was a Russian expert in the State Department as well as the Presidential interpreter. For more information see: Charles E. Bohlen, Witness to History, 1929-1969 (New York, 1973). 
pacity for aggression, whatever its present intentions." ${ }^{16}$ Not only did NSC-68 increase the assertiveness of U.S. foreign policy toward the Soviet Union, it pushed the budget cap on the military through the roof. The implementation of NSC- 68 gave the U.S. military the power it had been searching for, and allowed the administration to adhere to a more rigid anti-Soviet strategy.

NSC-68 was in itself a policy which set the "blueprint for waging the Cold war for the next twenty years," according to Gaddis. It stated that negotiations with the Russians were irrelevant because they would not be able to change their policies to meet the needs of the United States. Instead, it called for an increase in the armaments race with the development of the hydrogen bomb, which, the document stated, would offset the Russian atomic threat. In conjunction with increased nuclear force, the United States was to mobilize the American people both economically and morally as well as lead an alliance to support its international role. ${ }^{17}$ The central tone of NSC-68, writes John Fousek, was placed between the "need for an ambitious, comprehensive, long-term plan for U.S. policy and the need to ensure public support for that policy."18 In order for Truman and his advisors to receive public support for their intensified anti-Soviet agenda, the administration exacerbated the already existent public fears. Acheson wrote that NSC-68 was

\footnotetext{
${ }^{16}$ John Lewis Gaddis, Strategies of Containment: A Critical Appraisal of Postwar American National Security Policy (New York, 1982), p. 84.

${ }^{17}$ Walter LaFeber, America, Russia, and the Cold War, 1945-1990, 6th ed. (New York, 1991), pp. 9697.

${ }^{18}$ John Fousek, To Lead the Free World: American Nationalism and the Cultural Roots of the Cold War (Chapel Hill, 2000), p. 164.
} 
an "analysis of the [Russian] threat combined [with] the ideology of communist doctrine and the power of the Russian state into an aggressive expansionist drive." 19

Nitze and the coauthors of NSC-68 were also interested in the American public's opinion, because to them, the public was not making enough sacrifices to deal with the present Soviet threat. According to Nitze, Americans needed to be educated in the "new ideology" of national security. Acheson concurred, saying that the American people suffered from "a false sense of security." Robert Lovett, the new undersecretary of defense, also stressed that it was necessary for the public to understand that the United States was in "a war worse than any we have ever experienced," describing the current situation as "not a cold war," but "a hot war."20 It was the job of the government, in the phrase used by public relations expert and Assistant Secretary of State for Public Affairs Edward W. Barrett, to launch a "psychological scare campaign."21

This psychological scare campaign had already been set in motion with the public announcement on television of Senator Edwin C. Johnson (D-CO) that American atomic scientists had been exploring "what is known as the super-bomb" since the bombing of Hiroshima and Nagasaki. ${ }^{22}$ He expounded that "our scientists already have created a bomb that has six times the effectiveness of the bomb dropped at Nagasaki and they're not satisfied at all; they want one that has a thousand times the effect of that terrible bomb that was dropped at Nagasaki that snuffed out the lives of 50,000 people just like

\footnotetext{
${ }^{19}$ Dean Acheson, Present at the Creation: My Years in the State Department (New York, 1969), pp. 373-376.

${ }^{20}$ Hogan, $A$ Cross of Iron, p. 300.

${ }^{21}$ John Lewis Gaddis, Strategies of Containment: A Critical Appraisal of Postwar American National Security Policy (New York, 1982), p. 108.

22 "The President Orders Exploration of the Super Bomb," The Bulletin of Atomic Scientists 6 (March 1950): 66.
} 
that." Johnson continued, "That's the secret that's the big secret that the scientists in America are so anxious to divulge to the whole scientific world." ${ }^{23}$ But Senator Johnson was the person who excitedly revealed the intentions and capabilities of atomic scientists to a world already awed by the atomic bomb.

Johnson's public announcement moved national periodicals to set off a campaign of fear in the United States. U.S. News and World Report started to speculate on the power of thermonuclear energy. Under a picture of the devastation of Hiroshima, one article stated that a hydrogen bomb "could destroy 100 square miles, maybe 1000 or more." Under an aerial photo of an atomic explosion, the article noted that there was "no known limit to its size," and the bomb could easily destroy all of New York City. ${ }^{24}$ In its January 16, 1950 issue, Time described the energy of the hydrogen bomb in relation to that of the sun, while it compared the atomic bomb to mere matchsticks. Time also related the importance of the thermonuclear decision to that of the Soviet atomic detonation by stating that the "Russian atomic explosion had drastically clipped the atomic lead upon which a great deal of U.S. security and strategy was based." ${ }^{25}$ By the end of the month, Time was calling the H-bomb the "most powerful explosive weapon the world has yet dreamed of" and speculated that if the Russians were going to build an H-Bomb, the United States was going to as well. ${ }^{26}$ Newsweek was more technical in its estimates of the power of the hydrogen bomb. According to columnist Earnest K. Lindley, the destructive capability of the superbomb "might be ten to twenty times as great as that of the newer type uranium-plutonium bombs, which are reported to be approximately, six

\footnotetext{
${ }^{23}$ Ibid.

24 "Hydrogen Bomb: Next Superweapon?" U.S. News and World Report, January 13, 1950, pp. 21-22.

25 "National Affairs," Time, January 16, 1950, p. 19.

26 "National Affairs," Time, January 30, 1950, p. 11.
} 
times as powerful as the Hiroshima weapon."27 Although both Time and Newsweek were enthusiastic in their descriptions of thermonuclear destruction, both magazines commented that it was their belief that its development would jeopardize any chance for world peace.

Arguing that scientists had a moral obligation to participate in the creation of a world government, scientists Cuthbert Daniel and Arthur M. Squires asked in The Bulletin of Atomic Scientists if under world government it would be necessary to build hydrogen bombs. Stating "a world government's task would be easier if the community of scientists have a responsible attitude toward atomic super-bombs," both Daniel and Squires denounced other scientists that had not recognized the "world government movement.,"28

Life Magazine used two pages of picture to describe the implications of the H-bomb. The first set of images illustrated the power of fusion in relation to the sun. The second set showed an aerial view of Chicago with a dot in the middle of two concentric circles. The smaller circle was quite close to the dot, while the larger outside circle surrounded the city. The caption read: "Theoretical Destruction of Chicago." The dot represented ground zero and the smaller circle contained the destruction caused by an atomic bomb. The larger circle represented the destructive capabilities of the hydrogen bomb. ${ }^{29}$ Few words were needed to accompany this kind of visual information: its subliminal message was fear and imminent death.

Although the hydrogen bomb or "super bomb" had been in the development stages for years, it had not been given a high priority by the U.S. government. One reason for

\footnotetext{
${ }^{27}$ Earnest K. Lindley, "Facts About the Superbomb," Newsweek, January 30, 1950, p. 23.

${ }^{28}$ Cuthbert Daniel and Arthur M. Squires, "Scientists' Responsibilities on the Way to Peace, and After," The Bulletin of Atomic Scientists 5 (December 1949): 27.

29 "U.S. Learns It Can Make the H-Bomb," Life, January 30, 1950, p. 22-23.
} 
this was the limited defense budget. Research on the hydrogen bomb by atomic scientists would seriously cut into the budget allotted to atomic production. The government had feared that shifting the focus on an already tried and true method of atomic energy to an untested hydrogen bomb would not only reduce the production rate on the atomic bomb stockpile, but would also waste money. The Soviet atomic detonation changed this focus. "As soon as news of the Soviet explosion became known," writes Leffler, "champions of thermonuclear weapons stepped up their demand for money and personnel." ${ }^{, 30}$ Military planners felt that the possibility of a Super bomb would shift the balance of power back to the United States. When the Special Committee of the NSC met with the president to recommend the Super bomb project, Truman cut their presentation short, according to Richard Rhodes, by saying, "What the hell are we waiting for? Let's get on with it." The meeting ended after seventeen minutes.

Truman had made up his mind. That same day, January 31, 1950, President Truman announced to the world that he was directing "the Atomic Energy Commission to continue its work on all forms of atomic weapons, including the so-called hydrogen or super-bomb."31 Within the same speech, Truman identified world peace with American national security: "Like all other work in the field of atomic weapons, it is being and will be carried forward on a basis consistent with the overall objectives of our program for peace and security." 32 The hostile rhetoric of policy makers during this period was directed toward the Soviet Union, a country that in their view was preparing for eventual

\footnotetext{
${ }^{30}$ Leffler, A Preponderance of Power, p. 327.

${ }^{31}$ Rhodes, Dark Sun, p. 407.

${ }^{32}$ Harry S. Truman, Years of Trial and Hope, vol. 2 of Memoirs By Harry S. Truman (Garden City, 1956), p. 309. Truman also noted the importance of international atomic control while initiating thermonuclear development.
} 
aggression toward the United States. According to Truman and his advisors, "The USSR has already committed itself to defeat of the U.S., [and] Soviet policy is guided by the simple consideration of weakening the world power position of the U.S." ${ }^{33}$ In other words, war was more of a possibility in the near future than world peace.

Prior to this announcement, the JCS had alerted the president to the disastrous results if the United States did not invest in hydrogen bomb production. Senator Brien McMahon wrote Truman:

Any idea that American renunciation of the super would inspire hope in the world or that 'disarmament by example' would earn us respect is so suggestive of an appeasement psychology and so at variance with the bitter lessons learned before, during and after two recent wars that I will comment no further.

Further, McMahon stated that the advantages of the new weapon would "decisively outweigh the possible social, psychological, and moral objections." ${ }^{34}$

Until the announcement by the president, atomic scientists across America did not agree that the H-bomb should be built, nor did they know how to go about building one. The idea of the hydrogen bomb was scarcely advanced beyond the theoretical stages. Moreover, scientists did not agree on the implementation of thermonuclear weapons. The Federation of American Scientists (FAS) issued a statement after Truman's an-

\footnotetext{
${ }^{33}$ Study Prepared by the Director of the Policy Planning Staff, February 8, 1950, FRUS, 1950, vol. 1:National Security Affairs: Foreign Economic Policy: 145-147. That same document also notes, "There seems to be no reason to assume that the USSR will in the future necessarily make a sharp distinction between 'military aggression' and measure short of military aggression." Further, it had been U.S. policy to publicly discuss atomic disarmament while working to increase atomic production. It was suggested on September 23,1949, "it was the worst possible time for us to have the majority the U.N. plan [atomic controls] plan accepted as we now have such a tremendous superiority in our stockpiles of atomic weapons.... In summery, the U.S. should continue the development of a balanced military force...including the modernization of atomic production facilities... and simultaneously we should work up a program for general disarmament." Memorandum of Conversation, by the Deputy Assistant Secretary of State for United Nations Affairs, September 23, 1949 FRUS, 1949, 1: 171.

${ }^{34}$ Gaddis, Strategies of Containment, p. 81.
} 
nouncement saying, "If we make hydrogen bombs, the Russians will build them too."

Some scientists declared that the United States should not depend on security based on a monopoly of Super weapons. The director of the Theoretical Division at Los Alamos, Hans Bethe, "pulled together twelve scientists at the convention of the American Physical Society for a press conference," and declared, "No nation has the right to use such a bomb, no matter how righteous its cause. This bomb is no longer a weapon of war, but a means of extermination of whole populations. Its use would portray all the standards of morality." ${ }^{, 35}$ In response to their declaration, the New Republic questioned the U.S. government's intent to create an international "atomic-disarmament system." Since the U.S. proposals for international atomic control were based on the fact that the United States had an atomic monopoly, there was a brief flicker of hope that the United States would now take the lead in a more "realistic" approach to atomic control. "American newspapers have blessed the decision" to go forward with the hydrogen bomb, the New Republic informed its readers, "in the form of self-congratulatory editorials that avoid the real issue." The real issue, the magazine insisted, was the consequences of President Truman's decision, because he "has now presented America's solution, and with it he has reduced these hopes [for atomic energy control] and deepened despair. He has suggested that the best we can do to still the anxieties of mankind is to build bigger bombs and to restore, if possible, our former monopoly of absolute destructive power." Moreover, the United States had a moral obligation, the New Republic urged, because it was

\footnotetext{
${ }^{35}$ Lawrence S. Wittner, One World or None: A History of the World Nuclear Disarmament Movement Through 1953 (Stanford, 1993), p. 65. This declaration was printed as "Let Us Pledge Not to Use the H-Bomb First!" The Bulletin of Atomic Scientists 6 (March 1950): 75. Hans A. Bethe continued to beseech the American public and the scientific community to insist on international control of atomic weapons; see Hans A. Bethe, "The Hydrogen Bomb II," Scientific American 182 (April 1950): 18-23; Hans A. Bethe, "The Hydrogen Bomb," The Bulletin of Atomic Scientists 6 (April 1950): 99-104.
} 
the only country to actually use the atomic bomb. The Soviet Union, in comparison it was argued, had a morally stronger record on atomic armaments for several reasons: the Soviets had never used the bomb, they did not have a stockpile of atomic weapons, they had not threatened other nations with the bomb, nor had atomic power been used as a form of political pressure by the Russians. Instead, the New Republic stated, "Soviet leaders have insisted that they will not use the bomb as a weapon of expansion and they will build only enough bombs to protect their own nation." With this declaration, the New Republic was in agreement with Kennan and his preferred policy of non-aggression toward the Soviet Union. ${ }^{36}$ A cartoon printed in Time also highlighted with the illusions created by atomic weapons. In the drawing, a man is sitting in front of a large accounting book tallying up the dead, injured and missing of Hiroshima under the heading of ABomb. The facing page is titled H-Bomb. Below the cartoon, the caption reads, "And Now the Super-Duper . . . Also the end of an illusion." ${ }^{, 37}$

However, the issues on international atomic control would linger in the administration long after Truman's decision to build the hydrogen bomb. In August 1952, McMahon used the same subject to further the development of thermonuclear energy. According to his article "Survival-the Real Issue of Our Times," McMahon suggested that America "must build hundreds of hydrogen bombs to prolong the period in which aggression can be prevented by threat of American retaliation.” Throughout his article, not only does McMahon compare the power of the H-bomb to the A-bomb, he also insinu-

\footnotetext{
36 "The Hydrogen Bomb," New Republic, February 13, 1950, pp. 5-7.

${ }^{37}$ National Affairs, Time, February 13, 1950, p. 15.
} 
ated another war was inevitable. Although the overall argument is about disarmament, he was clearly arguing otherwise. ${ }^{38}$

According to Newsweek, American atomic scientists had "developed a 'Hiroshima complex;' they were appalled by the death and destruction which the A-bomb had wrought; and they detested the idea of developing an even more dangerous weapon., 39 But the periodical kindly excused the scientists when it was explained that they would carry through with the project because of patriotic reasons - and because of, I might add, the fear of repercussions.

Some scientists strongly supported the implementation of the Super bomb. Edward Teller was its chief proponent. He encouraged an all-out effort to build the H-bomb. Teller said, according to Rhodes, "If the Russians continue to make actual progress faster and if we loose the atomic armaments race, it will make little difference whether the reason has been the particular brilliance of Russian scientists or the exaggerated caution and thoroughness of our own group." The Federation of Atomic Scientists issued a statement, which said, "A thermonuclear breakthrough was indispensable to survival regardless of any other consideration., 40

Years later, Noble laureate I. I. Rabi recalled that for Truman "to have alerted the world that we were going to make a hydrogen bomb at a time that we did not even know how to make one was one of the worst things he could have done."41 According to Rhodes, the public hydrogen bomb debates of autumn 1949 that divided American scientists

\footnotetext{
${ }^{38}$ Brien McMahon, "Survival-the Real Issue of Our Times," The Bulletin of Atomic Scientists 8 (August 1952): 173-175.

39 "Why We'll Make the H-Bomb," Newsweek, February 13, 1950, pp. 19-20.

${ }^{40}$ Rhodes, Dark Sun, p. 390.

${ }^{41}$ Ibid., p. 408.
} 
"were little more than a White House public-relations ploy." Apparently it was necessary for the President to show he arrived at decisions in an orderly fashion and did not make rash judgments - although the president had previously stated his opinion about the importance of nuclear energy. ${ }^{42}$ Assistant Press Secretary Eben A. Ayers remarked in his diary that Truman had said that there "actually was no decision to make the $\mathrm{H}$ bomb," and that the money was already appropriated for to the AEC the prior fall. Ayers further wrote that the president "went on to say that we had to do it—make the $\mathrm{H}$ bomb - though no one wants to use it. But, he said, we have got to have it if only for bargaining purposes with the Russians."43

In his Memoirs, Truman justified his decision to build the Super bomb because it was the "one direction in which we held our commanding [strategic] lead." He further stated that with new developments, the atomic bomb could be put to alternate uses-all of which are military: "But we were also able to adapt the A-bomb to new uses, even to the point where it became possible to build atomic cannons, to put atomic warheads on guided missiles and atomic powered units into submarines." According to the president, "The power of the atom is the key importance to a peaceful world.",44

Within one week of the presidential announcement, the British arrested Klaus Fuchs, one of Britain's foremost atomic scientists, for spying for the Russians. Acheson believed that this event and the conviction of Alger Hiss for perjury and "other accusations" were used to create in the "public mind criticisms of American foreign policy to-

\footnotetext{
${ }^{42}$ Ibid., p. 407.

${ }^{43}$ Robert H. Ferrell, ed., Truman in the White House: The Diary of Eben A. Ayers (Columbia, 1991), pp. 340-341. Ferrell notes that Truman may have been interested in thermonuclear development for another reason: "If the Russians obtained [the H-Bomb] first, the president's position against the Republicans and conservative Democrats would become impossible."

${ }^{44}$ Truman, Years of Trial and Hope, p. 312.
} 
ward Europe and Asia with fears of disloyalty." ${ }^{45}$ Time sandwiched the announcement of the arrest of "Communist-Scientist Klaus Fuchs" within a story about Truman's decision to build the hydrogen bomb, which, "led a jittery Washington to wonder whether even the deepest of military or state secrets were safe from the USSR's agents." Reinforcing the president's decision, Time informed readers that it was already likely that the Russians were pursuing their own H-bomb project, and "if undeterred by the treat of retaliation in kind," the Russians would be capable of delivering a hydrogen bomb by any conventional means available. ${ }^{46}$ Newsweek also played upon widespread fears when it reported the H-bomb decision.

It was the fear of disloyalty that made American scientists second-guess themselves. In "Secrets Will Out," printed in The Bulletin of Atomic Scientists, it was announced that for four years the journal withheld an article by a Professor Thirring as well as other articles that contained information on thermonuclear explosions for fear that the government would implicate scientists for discussing classified information and because they feared that a discussion of the sort would "stimulate the atomic arms race and further exacerbate international relations." The Bulletin of Atomic Scientists charged Senator Johnson with breaking national security when he made his public announcement on the development of the Super:

It was left to the naïve and monumental indiscretion of Senator Johnson, and the obvious leaks of official information to journalists such as the Alsop brothers, to precipitate a public discussion of what has since become known as the 'hydrogen bomb,' in the American press. Apparently the only people who take secrecy in atomic matters seriously in this country are the muchabused scientists, who, according to Senator Johnson, cannot resist the 'yen'

\footnotetext{
${ }^{45}$ Acheson, Present at the Creation, p. 345.

${ }^{46}$ National Affairs, Time, February 13, 1950, p. 15.
} 
to tell everybody all they know about the atom. As soon as the subject gets out of the hands of the scientists (and of the equally maligned AEC) onto the desks of high military or civilian authorities, or Congressional Committees, 'top secrets' begin not to leak, but to pour out in torrents. ${ }^{47}$

The article noted that it was bad enough that the decision to build the atomic bomb was shrouded in secrecy, but the decision to build the hydrogen was altogether worse. Although only a handful of people would make the decision, it was the nation as a whole that would have carry the burden and possibly "generations to come may have to suffer their consequences." 48

Because the public was not involved in the decision making process, physicist Louis N. Ridenour wrote in Scientific American, the United States was becoming more removed from democracy. Not only had the government given the AEC "unusual powers, encroaching thereby on many of the principles basic to Western democracy," Ridenour pointed out, but the decision to build the fusion bomb was "curious [given] the production of a weapon uniquely suited to the destruction of the great cities around which our own economy and our civilization are built." Considering that the world now consists of "hotly nationalized fear and jealousy," it was clear that the Truman administration did not even contemplate the moral issues surrounding the decision. Ridenour emphasized the fact that "once it is decided that people are to be killed, the 'moral' question is fully settled; the instruments of hate killing are not at all affected with human or moral questions." With sarcasm, Ridenour continued, "It was probably more unpleasant to be dis-

\footnotetext{
47 "Secrets Will Out," The Bulletin of Atomic Scientists 6 (March 1950): 67. For more information on the Alsop brothers and their involvement in American opinion on the Hydrogen bomb see: Robert E. Merry, Taking on the World: Joseph and Stuart Alsop_Guardians of the American Century (New York, 1996), pp. 186, 257-61, 264, 267-8.

48 "Secrets Will Out," The Bulletin of Atomic Scientists.
} 
emboweled by the 18-inch sword of the Roman soldier than it would be to vanish in the flash of a nuclear reaction. $" 49$

Backing the presidential decision fully, Newsweek stated, "The ugly truth was that President Truman had no choice" about the H-bomb given the current world situation, because the nation's only safety "lay in out producing Russia." The periodical noted the unpreparedness of the United States against the Soviet Union by pointing out the strength of the Russian military. According to Newsweek, "The Russians already had the greatest army in the world, the greatest air force, and the greatest under seas fleet. If they could gain atomic supremacy as well—and by default at that — there would be nothing to stop them from conquering the world." Apparently Americans were "asleep" when it came to Soviet intelligence. With the help of "American, Canadian and British Communists," 50 Russians had easy access to intelligence-controlled atomic information. Without explicitly saying so, the article implied that Americans needed to look over their shoulders to report any suspicious activity, but most importantly, Americans needed to be distrustful of communists because they were spies.

Throughout the February 13, 1950 edition of Newsweek the Russians were the object of criticism, which implied that Americans were in the past not only too trustworthy of them, but also uninformed. Accordingly, Newsweek reminded the public that it was the Russians who had the strategic advantage: "Russia with its totalitarian system can disperse industry, conscript troops, recruit slave labor, divert raw materials, workers, technicians, and scientists from civilian to military production, and concentrate its entire na-

\footnotetext{
${ }^{49}$ Louis N. Ridenour, "The Hydrogen Bomb," Scientific American 182 (March 1950): 11-15.

50 "Hydrogen Age...Whither America?" Newsweek, February 13, 1950, pp. 17-18.
} 
tional effort on preparations for war. If the Russian people object, the Russian police can simply shoot them." ${ }^{, 51}$ The article implied that not only were the Russians preparing for a war they had every means of winning, but also they had something the United States did not have: 100 percent national compliance.

With the development of thermonuclear power, many American did not feel that world peace was in the near future. David Lawrence, in an article for U.S. News and World Report, asked: “When will Man's inventive genius be turned toward a constructive force that can really assure peace in the world?" Lawrence went against the grain when he wrote that the U.S. government needed to recognize that those who rule the Soviet Union did not make the decisions that rule the world. He further stressed that

The American people have been led to believe that everything that could be done in diplomacy has been done, and that if war comes, it will be the act of an aggressor-we shall be blameless. Even to raise slight doubts about the correctness of our own course and to ask for a careful examination of the equalities of our position in the past is to bring down on the questioner accusations of "appeasement" or of submission to a potential enemy.

David Lawrence was not only questioning the act of the hydrogen-bomb decision, he was questioning the very course of U.S. foreign policy. In his article, there was not only a fear of a future war, but there was a fear of the consequences of speaking against government policies. Apparently, he was willing to take the chance. Lawrence believed that the United States should take the initiative in peace talks, which in turn would set the world example for peace. "There is a force greater than propaganda," Lawrence wrote in closing, "it is the force of truth and fairness based on honest self-examination." 52

\footnotetext{
51 "Significance of the H-Bomb, and America's Dilemma," Newsweek, February 13, 1950, p. 20.

${ }^{52}$ David Lawrence, "-And When the Peace Bomb?" U.S. News and World Report, February 10, 1950 , p. 29. This article also refers to the arrest of Klaus Fuchs for espionage.
} 
American Christians supported Truman's decision, but continued to question the thermonuclear implication on the "Christian conscience." Commonweal gave an apocalyptic view of the moral obligations of the United States

It has been repeatedly made all too plain that any sign of weakness, appeasement, or "disarmament by example" simply eggs on a constantly expanding aggressor. To rely on inferior weapons would be to expose ourselves to unnecessary slaughter and to abandon Western Europe, and perhaps eventually our own country, to a dictatorship that tramples basic human rights and makes life unendurable.

The Christian periodical further stated that the president had made the only decision that was possible given the circumstances, and that it would not "condemn his decision as morally evil." What was clearly morally evil, the journal insisted, was the Soviet Union, not American intentions. ${ }^{53}$

While everyone paid closest attention to what was most important to them, began an article in Life, "certain forces were in motion; they were to result in decisions of profound meaning to many millions of people, and to shock them into understanding, more deeply than ever, what the meaning was." Although this language sounded very dramatic, these words and other political events were laced between traditional feminine concerns such as the birth of Ingrid Bergman's baby, National Youth Week and gossip on the Metropolitan Opera Company, therefore cushioning the blow of international events and national concerns. ${ }^{54}$ Life did capture, however, the persistent fear of the

\footnotetext{
53 "Week By Week," Commonweal, February 17, 1950, p. 499.

${ }^{54}$ The opening paragraph of the story is worth quoting in full: "The momentous week began like any other, with everybody paying closest attention to what seemed to concern him most. Thus President Truman took thought about how to phrase his decision to build the hydrogen bomb, Ingrid Bergman was urgently concerned with the imminent birth of her baby and Lauritz Melchior was busy preparing to quit the Met. Opera Company. A number of people bent every effort to see the week should be remembered as National Kraut and Frankfurter Week; a number of others strove to make National
} 
country and told its readers that they were not alone. In response to how he now thought about the atomic bomb, one man uncomfortably replied: "I just feel better, when I don't think about it." According to Life, he "wasn't being complacent or putting his dead in the sand, but it did seem to be pretty useless to worry about something that, like tomorrow's sunrise, was entirely out of his hands. But for anyone who reads the papers or listens to the radio, or couldn't afford a desert island, it was getting harder all the time not to worry and to avoid thinking about it.

In other words, Life was letting its readers know that it was all right to be afraid of the future and that most Americans were scared. Time did not approach public fear very differently. It let its readers know that fear was felt throughout the country even if another war was not at hand. "I don't think the public understands it," a barber said in response to the H-bomb, "that's why they don't talk much about it." Another man said that he skipped over the news of the H-bomb in the newspapers. When he looked at his neighbor, he thought, "How can that fool sit there and read how they are going to blow him up and never bat an eye?" According to Time, the United States was in an "atomic rat race." $" 56$

U.S. News and World Report had a different approach. It implied acceptance of the hydrogen-bomb project because it would soon produce practical uses for atomic energy. Although the "top emphasis now is on wartime uses of the atom," the periodical stated,

\footnotetext{
Youth Week even more memorable. Around the globe, others were being single-minded about deluges, droughts and debts. And in Harwell, Britain's big atomic-research center, an unobtrusive physicist named Klaus Emil Julius Fuchs went about his top-secret work with the satisfied feeling of a man who has recently won a promotion and a raise... "A Week of Shock and Decision," Life, February 13, 1950, pp. 36-37.

${ }_{55}^{55}$ Ibid.

56 "National Affairs," Time, February 13, 1950, p. 15.
} 
"civilian uses are gaining importance, speeding the industry's growth." The emphasis of the article was on the exciting new technology of the near future. In explaining atomic industrial expansion, the civilian aspects of the project were stressed, and it was implied that a better future for Americans if not all of mankind would be a probable consequence. ${ }^{57}$ But several pages later, in another article, the unlimited power of the hydrogen bomb was described. With a photo of President Truman looking concerned, U.S. News and World Report related the unquestionable destructive possibilities of thermonuclear power: "The thousand-power H-bomb would be destructive over an area about 13 miles from the center of the explosion. That would mean destruction of around 530 square miles. That would be larger than the area of Los Angeles." 58

By the end of February, U.S. News and World Report had shifted its concern from atomic warfare to the incapacitated state of the U.S. Navy through postwar military demobilization and the very public revolt of the Admirals. ${ }^{59}$ In comparison, the magazine stated, the Russians "were known to be building toward a goal of 1000 submarines in the next few years," and they already possessed a Navy that exceeded the "numerical strength of the active U.S. Navy." The magazine also implied that the U.S. military was currently preparing for a future war with Russia as the assumed target and the military was therefore reassessing the naval strength of the United States. ${ }^{60}$

\footnotetext{
57 "Atom Becomes Big Business at Billion Dollars a Year: Military Speed-up Draws Civilian Use Closer," U.S. News and World Report, February 10, 1950, pp. 11-13.

58 "How H-Bomb Would Work and What It Could Do," U.S. News and World Report, February 10, 1950 , p. 18.

${ }^{59}$ Mark Perry, Four Stars (Boston, 1989), pp. 8-20. Internal disputes between the navy, air force, and the army concerning power, funding, and atomic control during 1949 were known as the "Revolt of the Admirals."

60 "Atomic-Age Battleships: Plans for Rocket Warfare," U.S. News and World Report, February 3 , 1950 , p. 28.
} 
Continuing with the war theme, Time reported on the "Hydrogen Hysteria" caused by information that scientists were giving to the public in reference to thermonuclear power. Harrison Brown of the University of Chicago announced at a radio round table that the "blast effects of hydrogen bombing will only be the beginning; the radioactive effects will be far worse," and he compared radioactive particle to a swarm of invisible locusts. Brown gave vivid descriptions of an American attack and of a Soviet attack, both of which could be compared to Armageddon. In describing how the United States might attack the USSR, Brown said all that is necessary "is to explode large hydrogen bombs on a line extending north \& south across Europe. The radioactivity 'would be carried eastward by the winds, destroying all life within a strip 1500 miles wide, extending from Leningrad to Odessa, and 3000 miles deep, extending from Prague to the Ural Mountains." But it was his description of the devastation that could be done to the United States that was clearly the most frightening. The Soviet Union could explode bombs in the Pacific 1000 miles west of California and "their radioactivity, drifting eastward, would lawnmower the whole U.S. reaching and sterilizing New York in about five days." $" 61$

Other physicists participated in this discussion. Leo Szilard said that, "fifty tons of neutrons released by hydrogen fusion could ring the earth with a radioactive dust layer capable of killing the earth's entire population." Both Frederick Seitz and Hans Bethe agreed. This led others to charge that scientists were becoming alarmists. It was feared that this would ultimately result in "helping to frighten the U.S. public into forcing dangerous concessions to Russia." In their defense, Bethe and Seitz said "that the prevailing

\footnotetext{
61 “Science," Time, March 6, 1950, pp. 88-89.
} 
atmosphere of fearful secrecy makes it almost impossible for the full facts to be known. If the world does acquire the ability to commit suicide, the world's people, they insist, should be told."62

In an interview with U.S. News and World Report, member of the AEC Lewis L. Strauss tried to calm public fears about the effects of the hydrogen bomb, but was largely unsuccessful. Strauss observed that atomic weapons were not the only method of wreaking havoc on a population. "Man-made plagues and diseases," he said, "are no less terrible to contemplate." When asked if Americans were worrying enough about bacteriological warfare, Strauss replied, "I would make a distinction between worrying and giving sober thought to the situation and making reasonable preparations against eventualities." In response to a question concerning the results of a Soviet detonation of an atomic bomb off the coast of the United States, Strauss would not comment. ${ }^{63}$

Albert Einstein opposed the path the United States was taking. He deplored the state of fear and distrust expressed by Americans toward the Soviet Union. The hydrogen bomb may vanquish the enemy, he wrote; however, "it was incapable of getting rid of the mentality created by the war." 64 The heavy weight of sorrow filters through the article. Edward Teller's essay in The Bulletin of Atomic Scientist had just the opposite effect. His energy and excitement concerning the hydrogen project is apparent. Teller, rather than lamenting over the issue-maybe because it was his idea-told scientists that

\footnotetext{
${ }^{62}$ It is interesting to point out that in a footnote, Time used a nursery tale to illustrate the consequences of such an action: "Chicken Little was hit on the head by an acorn. She thought that the sky was falling. Her friends Ducky Lucky and Goosey Loosey got panicky too. Then Foxey Loxey led them all into his bombproof cave and ate them up." Ibid.

63 "Limits on the Atomic Bomb: An Interview with Lewis L. Strauss," U.S. News and World Report, March 17, 1950, pp. 28-31.

${ }^{64}$ Albert Einstein, "Arms Can Bring No Security," The Bulletin of Atomic Scientists 6 (March 1950): 71 .
} 
it was their patriotic and moral duty to build the bomb: "It is the scientist's job to find the way in which [the laws of nature] can serve the human will. However, it is not the scientist's job to determine whether a hydrogen bomb should be constructed, whether it should be used, or how it should be used." ${ }^{65}$ Harold C. Urey exclaimed that U.S. officials had "neurotic fears" that were the determining factor in building the hydrogen bomb. ${ }^{66}$

Therefore, even after the decision to build the hydrogen bomb had been announced by the president, American scientists were not unified on their views on the necessity of thermonuclear weapons. Because the building of the H-bomb could only result in a devastating weapon, many physicists saw the moral implications. They were afraid of the future consequences of such a project. Not only would a successful hydrogen bomb initiate an arms race with the Soviets, many atomic scientists felt, it would also have harmful psychological effects that would last for generations.

Hanson W. Baldwin, of The New York Times, discussed the psychological aspect of atomic warfare in his article, "The Strategy for Two Atomic Worlds." He stated that "those who say that 'nothing has been changed' merely flee reality." According to Baldwin, the U.S. government needed not only focus on the hydrogen bomb, there also needed to be an emphasis on public safety and city planning. "Most importantly," he wrote, "there has been little progress - except on paper - toward the development of an adequate civil defense program." Within his brief article, Baldwin used graphic descriptions of what Americans needed to do to survive an atomic war. He was not gentle in

\footnotetext{
${ }^{65}$ Edward Teller, "Back to the Laboratories," The Bulletin of Atomic Scientists 6 (March 1950): 71.

${ }^{66}$ Harold C. Urey, "Should America Build the H-Bomb?" The Bulletin of Atomic Scientists 6 (March 1950): 72.
} 
what was to be expected, but stated that he had confidence that Americans would be able to make the "psychological adjustment." Scientists that "a new dark age would begin on earth" in the event of a war with nuclear weapons. The hydrogen bomb would only bring "mass slaughter." In his view, "whomever wants to use the hydrogen bomb in our conflict with Russia . . . is adhering to the old fallacy that the ends justify the means. The fallacy is the more obvious because our conflict with Russia is mainly about means." ${ }^{\text {,68 }}$ Newsweek reported that a physicist of the University of Chicago's Institute for Nuclear Studies, James R. Arnold, attempted to negate Leo Szilard's claim "that the hydrogen bomb could be rigged to destroy the whole human race in a torrent of radioactive dust." But rather than dispute Szilard's claim, Arnold confirmed it. ${ }^{69}$ Again periodicals were depicting a future world war; however, their descriptions were more graphic and more apocalyptic.

The press was on the warpath in its reporting on atomic, hydrogen and advanced technological warfare. Interestingly, some opposing views of the Hydrogen bomb were for practical reasons. Robert F. Bacher, former Atomic Energy Commissioner, did not agree that the H-bomb had any practical use. According to him, it was too big, too hard to manipulate and not a guarantee to victory. ${ }^{70}$ In the August-September 1950 issue of The Bulletin of Atomic Scientists, Irving L. Janis of the Department of Psychology at Yale University wrote an article called the "Psychological Problems of A-Bomb Defense." Janis described the consequences of being a survivor in an atomic attack by relat-

\footnotetext{
${ }^{67}$ Hanson W. Baldwin, "Strategy for Two Atomic Worlds," Foreign Affairs: An American Quarterly Review 28 (April 1950): 386-397.

${ }^{68}$ Hans A. Bethe, "The Hydrogen Bomb," The Bulletin of Atomic Scientists 6 (April 1951): 99-104.

69 "Science," Newsweek, October 30, 1950, pp. 58-59.

${ }^{70}$ Robert F. Bacher, "The Hydrogen Bomb III," Scientific American 182 (May 1950): 11-15; "Science," Time, May 15, 1950, pp. 74-75.
} 
ing segments of interviews from those that survived in Hiroshima and Nagasaki. It is important to note that this article was put together in cooperation with the U.S. Department of Defense and the U.S. Atomic Energy Commission. Although the Bulletin of Atomic Scientists stated that the article was not intended for "the layman, but designed rather to give every technically interested person-municipal authorities, waterworks, civil, utility, transportation, engineers, etc.-an understanding of the effects of this enormous release of energy when used as a weapon in war." The article made clear that the destructive capabilities of an atomic bomb could mean traumatic and demoralizing event. The article itself was a call for mental and physical preparedness by the American public. $^{71}$

The National Security Council on January 11, 1951 announced that it considered the United States to be in a "war of survival," against the Soviet Union and that it was losing that war. NSC-100 recommended, "Every American citizen should realize that the atomic supremacy currently held by the United States in diminishing month by month," and that they should also realize "that neither this country nor any other country can buy time against the Soviet in the race for atomic power." In fact, the document stressed that the exact opposite was true, because "from here out the Soviet will gain monthly in its relative atomic strength against the rest of the world." The document concluded that the "current defense build-up" was inconsistent with survival. ${ }^{72}$ In other words, the United States needed to be prepared for a nuclear attack in more ways than simply militarily.

\footnotetext{
${ }^{71}$ Irving L. Janis, "Psychological Problems of the A-Bomb," The Bulletin of Atomic Scientists 6 (August-September 1950): 256-262.

${ }^{72}$ Report to the National Security Council by the Chairman of the National Security Resources Board, January 11, 1951 FRUS, 1951, vol. 1: National Security Affairs; Foreign Economic Policy: 5-18.
} 
On January 12, 1951, almost exactly a year after Truman's announcement to build the hydrogen bomb, the president signed a bill creating a federal Civil Defense Administration (CDA). The acceptance of the need to have a federally funded civil defense program had psychological implications. According to the mayor of Milwaukee Frank P. Zeidler, the bill not only served to create a "feeling of futility and helplessness," it also was an acceptance of the "defenselessness of the cities both because the weapons of offense have surpassed the weapons of defense and because such weapons of defense as may exist are inadequate." ${ }^{, 73}$ By the end of the summer, however, U.S. News and World Report was reporting about "fantastic weapons" that had the capability to intercept an atomic attack. These weapons, the article stated, would give Americans security they would be able to feel. Although the emphasis of American protection was on military developments, the magazine highlighted the family car as a potential bomb shelter. ${ }^{74}$

Almost immediately after the creation of the CDA, there was government concern regarding the lack of public interest reflected in the low number of volunteers. The reason for this, according to The Bulletin of Atomic Scientists, was "largely from the fatalistic attitude resulting from the well-known statement: 'There is no defense against the atomic bomb." Although he urged American citizens to participate in civil defense programs, the president reinforced the fatalistic view of atomic warfare by stating that it was impossible to prevent a bombing of the United States. ${ }^{75}$ On April 22, 1952, Civil Defense leaders were invited to the Nevada Test Site to observe an atomic blast. Frank P. Zeidler was one of the witnesses to the explosion. In his statement to the Bulletin of

\footnotetext{
${ }^{73}$ Frank P. Zeidler, "Local Government Looks at the Civil Defense Act," The Bulletin of Atomic Scientists 7 (February 1951): 57-58.

74 "New Defense Against Atom Bomb," U.S. News and World Report, September 21, 1951, pp. 11-13.

${ }^{75}$ Arthur H. Jaffey, "Civil Defense News," The Bulletin of Atomic Scientists 7 (June 1951): 192.
} 
Atomic Scientists, he believed that "the test, the accompanying television show, and the pictures, might have laid the groundwork for panic in American cities. ${ }^{, 76}$

The public hysteria and scientific concern created by Truman's decision to build the hydrogen bomb had tremendous psychological implications. With regularity, the press was exhibiting examples of atomic destruction. The discourse in newspapers and periodicals was about armaments and war. The underlining current was a theme of constant preparedness. The atomic bomb won the acceptance of the American public because it had won the war. The decision to build the hydrogen bomb was made in a time of peace. Ultimately, this was what was so frightening. There was no real reason, many Americans felt, to develop thermonuclear weapons that were only capable of being used in warfare. Furthermore, there was not any proof that the Russians were working toward the same goal. There was some public discussion on international atomic control prior to the hydrogen bomb project, and increasingly many Americans feared that the discourse on a world government could not take place. The world was soon to be governed by American thermonuclear power.

\footnotetext{
${ }^{76}$ Frank P. Zeidler, "Civil Defense and the Nevada Tests," The Bulletin of Atomic Scientists 8 (August 1952): 204.
} 


\section{Conclusion}

Post-revisionist historians conclude that President Harry S. Truman did the best he could considering the circumstances of the postwar period. Melvin P. Leffler believes that Truman utilized a prudent policy. ${ }^{1}$ Arnold A. Offner has a more critical view of the president noting that his "presumptions about the political-economic-military-moral superiority of the U.S. led him to believe that he could order the world on America's terms, he ascribed only dark motives to nations or leaders who resisted its will."2 John Lewis Gaddis feels that foreign policy during the early years of the Cold War was in direct response to Soviet provocations. ${ }^{3}$ Of lesser importance, however, Frank Kofsky argued that the administration needlessly enlarged the Soviet threat to further its own foreign policy goals.

My contribution, on the other hand, is to show that Truman and his advisors sought to fashion a prudent response to the Soviet Union, while seeking to further American security interests. I claim that the search for prudence was often distorted or made irrelevant by the environment in which it took place.

The discourse of fear used by the Truman administration and enhanced in the press created a climate of fear among the American people. This fear was highlighted by weekly periodicals with bold headlines throughout the early Cold War years. In fall 1945, almost thirty-seven percent of American believed that Russia was a peace-loving

\footnotetext{
${ }^{1}$ Melvin P. Leffler, A Preponderance of Power: National Security, The Truman Administration, and the Cold War (Stanford, 1992), p. 36.

${ }^{2}$ Arnold A. Offner, Another Such Victory: President Truman and the Cold War, 1945-1953 (Stanford, 2002), p. 458.

${ }^{3}$ John Lewis Gaddis, The United States and the Origins of the Cold War, 1941-1947 (New York, 1972).
} 
country. ${ }^{4}$ By summer 1947, fifty-two percent of Americans felt that the Soviet Union wanted to rule the world. ${ }^{5}$ The public felt that the main causes of disagreement between the United States and the Soviet Union were fear and distrust. ${ }^{6}$

Although the Truman administration utilized fear to further its foreign policies, the fear instilled within the public made it more difficult to achieve its goals. Congress eventually did not adopt universal military training because a "system of selective service seemed more in line with traditional notions of the citizen-soldier."7 Most Americans supported the enactment of UMT because of their fears of the unknown. The Soviet Union was rapidly being perceived by the press as the future aggressor toward the United States, and to the American public UMT appeared to provide the security it needed. The Soviet detonation of an atomic device provided the press with the ammunition to propagate intense national fear, and because of perceived aggressive Soviet behavior a third world war was predicted. ${ }^{8}$ When Truman decided to build the hydrogen bomb, however, he did not receive a unified response from the American public. Scientists were also divided on the decision. Many Americans feared what the hydrogen bomb was capable of, while many were also afraid that the Soviet Union was already building the H-Bomb. In summer 1950, sixty-nine percent of the public believed that the United States should "go ahead" and build the hydrogen bomb because, "we

\footnotetext{
4 “The Quarter's Polls," Public Opinion Quarterly 9 (Fall 1945), p. 388.

5 "The Quarter's Polls," Public Opinion Quarterly 11(Summer 1947), p. 318.

6 “The Quarter's Polls," Public Opinion Quarterly 11(Spring 1947), p. 147.

${ }^{7}$ Michael J. Hogan, A Cross of Iron: Harry S. Truman and the Origins of the National Security State, 1945-1954 (New York, 1998), p. 158.

${ }^{8}$ A Spring 1951 poll showed that $49 \%$ of Americans believed that the United States should increase production of "planes, tanks, guns, and other war equipment" and reduce the production of unnecessary foods such as televisions, refrigerators, and automobiles. "The Quarter's Polls," Public Opinion Quarterly 16 (Spring 1947), p. 169.
} 
must be prepared." On the other hand, in The Bulletin of Atomic Scientists the decision to build and participate in the hydrogen bomb project was highly debated. The decision to build the atomic bomb had been top secret and Americans did not learn of atomic capabilities until after the destruction of Hiroshima and Nagasaki. The atomic bomb was praised by most Americans because it won the war for the United States and from the very beginning alternative uses for atomic energy were discussed. As a whole, the atomic bomb was accepted. The hydrogen bomb, however, was not so easily accepted because the United States was suppose to be initiating world peace, and the only known use for the H-Bomb was its destructive power.

Thus, the closing of World War II did not bring the anticipated world peace sought by Americans. Instead the new world environment created by the early years of the post war brought uncertainty and fear to the American people.

9 “The Quarter's Polls,” Public Opinion Quarterly 14 (Summer 1950), pp. 372-373. 


\section{Bibliography}

\section{PRIMARY SOURCES}

\section{Books:}

Acheson, Dean. Present at the Creation: My Years in the State Department. New York: W.W. Norton \& Company Inc., 1969.

Bohlen, Charles E. Witness to History 1929-1969. New York: W.W. Norton \& Company Inc., 1973.

Bohlen, Charles E. The Transformation of American Foreign Policy. New York: W.W. Norton \& Company Inc., 1969.

Dulles, John Foster. War or Peace. New York: The MacMillan Company, 1950.

Ferrell, Robert H., ed. Truman in the White House: The Diary of Eban A. Ayers. Columbia: University of Missouri Press, 1991.

Ferrell, Robert H., ed. Off the Record: The Privet Papers of Harry S. Truman. New York: Harper \& Row, Publishers, 1980.

Harriman, W. Averell. America and Russia in a Changing World: A Half Century of Personal Observation. Garden City: Doubleday \& Company, Inc., 1971.

Harriman, W. Averell and Elie Abel. Special Envoy to Churchill and Stalin 1941-1946. New York: Random House, 1975.

Kennan, George F. Memoirs 1925-1950. Boston: Little, Brown and Company, 1967.

Millis, Walter, ed. and E.S. Duffield. The Forrestal Diaries. New York: The Viking Press, 1951.

Stimson, Henry L. and McGeorge Bundy. On Active Service in Peace and War. New York: Harper \& Brothers, 1948.

Truman, Harry S. Memoirs of Harry S. Truman: Year of Decisions. Vol. 1. Garden City: Doubleday \& Company Inc., 1955. 
Truman, Harry S. Memoirs of Harry S. Truman: Years of Trial and Hope. Vol. 2. Garden City: Doubleday \& Company Inc., 1956.

\section{Government Documents:}

Etzold, Thomas H. and John Lewis Gaddis, eds. Containment: Documents on American Policy and Strategy, 1945-1950. New York: Columbia University Press, 1978.

United States. Department of State. Foreign Relations of the United States, 1952-1954, Vol. 2, Part 2: National Security Affairs. Washington D.C. Government Printing Office, 1984.

United States. Department of State. Foreign Relations of the United States, 1951, Vol. 1: National Security Affairs; Foreign Economic Policy. Washington D.C.: Government Printing Office, 1979.

United States. Department of State. Foreign Relations of the United States, 1950, Vol. 1: National Security Affairs; Foreign Economic Policy. Washington D.C.: Government Printing Office, 1977.

United States. Department of State. Foreign Relations of the United States, 1949, Vol. 1: National Security Affairs; Foreign Economic Policy. Washington D.C.: Government Printing Office, 1976.

United States. Department of State. Foreign Relations of the United States, 1948, Vol. 4: Eastern Europe; The Soviet Union. Washington D.C.: Government Printing Office, 1974.

U.S. Congress. Hearing Before the Joint Committee On Atomic Energy. $81^{\text {st }}$ Congress, $1^{\text {st }}$ sess., February 1949. Washington D.C.: Government Printing Office, 1949.

U.S. Congress, House. Hearings Before the Committee on Expenditures in the Executive Departments: Investigation of War Department Publicity and Propaganda in Relation to Universal Military Training. Pursuant to H. Res. 90 and 197. $80^{\text {th }}$ Congress, $2^{\text {nd }}$ sess., January 1948. Washington D.C.: Government Printing Office, 1948.

U.S. Congress, House. Hearings Before the Select Committee on Postwar Military Policy. Pursuant to H. Res. 465. $79^{\text {th }}$ Congress, $1^{\text {st }}$ sess., Part 1. June 1945. Washington D.C.: Government Printing Office, 1945.

U.S. Congress, Senate. Hearing Before the Committee on Armed Services on Universal Military Training. $80^{\text {th }}$ Congress. $2^{\text {nd }}$ sess., March-April 1948. Washington D.C.: Government Printing Office, 1948. 


\section{Internet Sites:}

Statement by the President of the United States, August 6, 1945. Internet site: http://www.enviroweb.org/issues/nuketesting/hiroshima/truman1.htm.

Trinity Test, July 26, 1945. Eyewitness Accounts-Edwin M. McMillan. Internet site: http://www.dannen.com/decision/momillan.html

Trinity Test, July 26, 1945. Eyewitness Accounts-Enrico Fermi. Internet site: http://www.dannen.com/decision/mcmillan.html

Trinity Test, July 26, 1945. Eyewitness Accounts-Kenneth Greisen. Internet site: http://www.dannen.com/decision/greisen.html

U.S. Nuclear Testing from Project Trinity to the Plowshare Program. Internet site: http://www.enviroweb.org/issues/nuketesting/atmosphr/ustests.htm

\section{Periodicals:}

"Atom Becomes Big Business at Billion Dollars a Year: Military Speed-up Draws Civilian Use Closer." U.S. News and World Report, February 10, 1950. pp. 11-13.

"Atom Threat: Boost for Army." U.S. News and World Report, October 7, 1949. pp. 20-21.

"Atomic-Age Battle Ships: Plans for Rocket Warfare." U.S. News and World Report, February 3, 1950. p. 28.

“Atomic Scoop.” New Republic, March 3, 1947. p. 6.

"Atomic Force in War and Peace: Sequel to Bombing of Japan." U.S. News and World Report, September 7, 1945. pp. 28-29.

Bacher, Robert F. "The Hydrogen Bomb III." Scientific American 182 (May 1950): 11-15.

Baldwin, Hanson W. "Strategy for Two Atomic Worlds." Foreign Affairs: An American Quarterly Review 28 (April 1950): 386-397.

Baldwin, Hanson W. “Conscription for Peacetime?” Harper's Magazine 190 (March1945): 389-300. 
Bethe, Hans A. "The Hydrogen Bomb" The Bulletin of Atomic Scientists 6 (April 1950): 99-104.

Bethe, Hans A. “The Hydrogen Bomb II.” Scientific American 182 (April 1950): 18-23.

Blatt Jr., William L. “Why I Advocate U.M.T.” The Nation, April 24, 1948. p. 439.

“The Bomb: The Story Explodes Around the World." Newsweek, October 3, 1949. p. 17.

“Can Our Civilization Survive the Atomic Bomb?” Look, October 30, 1945. p. 71.

“Can Russia Deliver the Bomb?” Life, October 10, 1949. pp. 44-45.

Chisholm, G. Brock. “Can Man Survive?” The Nation, July 27, 1946. pp. 93-96.

"Critical Time for A-Bomb World is Two Years Hence: An Interview with Dr. R.E. Lapp." U.S. News and World Report, September 30, 1949. pp. 16-19.

Daniel, Cuthbert, and Arthur M. Squires. "Scientists' Responsibilities on the Way to Peace, and After." Bulletin of Atomic Scientists 5 (December 1949): 27.

de Seversky, Major Alexander P. "Atomic Bomb Hysteria." The Reader's Digest, 48 (January 1946): 121-126.

"Defense in Atomic Age: Plans for Big U.S. Forces." U.S. News and World Report, September 28, 1945. pp. 22-23.

“The Deportation Cases.” The Nation, March 13, 1948. p. 291.

"Did the Soviet Atomic Bomb Come Sooner than Expected?" Bulletin of Atomic Scientists 5 (October 1949): 262-264.

"Editorial." The New Republic, June 23, 1947. p. 11.

Einstein, Albert. "Arms Can Bring No Security." The Bulletin of Atomic Scientists 6 (March 1950): 71.

“ 'Fringe' Cities: Answer to A-Bomb.” U.S. News and World Report, October 7, 1949. pp. 18-19.

Eliot, George Fielding. "Science and Foreign Policy." Foreign Affairs: An American Quarterly 23 (April 1945): 378-387.

Engel, Leonard. "Science Notebook." The Nation, August 21, 1948. p. 231. 
Engel, Leonard. "Fear in Our Laboratories." The Nation, January 7, 1948. p. 63.

Engel, Leonard. “The Scope of Biological Warfare.” The Nation, July 26, 1947. p. 93.

“Government's Role in Science: A Key to World Leadership." U.S. News and World Report, October 19, 1945. pp. 30-31.

"The Hearst Newspapers Have Always Led in Exposing and Opposing COMMUNISM." U.S. News and World Report, October 10, 1945. pp. 46-47.

"How H-Bomb Would Work and What It Could Do." U.S. News and World Report, February 10, 1950. p. 18.

“How Many Atom Bombs?” U.S. News and World Report, July 1, 1949. pp. 22-23.

"How U.S. Will Fight Next War: Air Attack Only A Beginning." U.S. News and World Report, August 26, 1949. pp. 11-14.

“How was the Atomic Explosion Detected?" Life, October 3, 1949. pp. 18-19.

“Hydrogen Age...Whither America?” Newsweek, February 13, 1950. pp. 17-18.

“The Hydrogen Bomb.” The Bulletin of Atomic Scientists 6 (April 1950): 99-104.

“The Hydrogen Bomb." New Republic, February 13, 1950. pp. 5-7.

"Hydrogen Bomb: Next Superweapon?" U.S. News and World Report, January 13, 1950. pp. 21-22.

Ickes, Harold L. “The Russian A-Bomb.” New Republic, October 10, 1949. p. 17.

"Is Another World War Near? Growth of 'Big 3' Dissension." U.S. News and World Report, March 22, 1946. pp. 19-21.

Jaffey, Arthur H. "Civil Defense News." The Bulletin of Atomic Scientists 7 (June 1951): 192.

Janis, Irving L. "Psychological Problems of the A-Bomb" The Bulletin of Atomic Scientists 6 (August-September 1950): 256-262.

Kirchwey, Freda. “The President's Message.” The Nation, March 27, 1948. p. 341.

Laurence, William L. "How Soon Will Russia Have the A-Bomb?" The Saturday Evening Post, November 6, 1948. p. 23. 
Lawrence, David. “- And When the Peace Bomb?" U.S. News and World Report, February 10, 1950. p. 29.

Lawrence, David. “The Road to World War III?” U.S. News and World Report, June 7, 1946. pp. 28-29.

"Letters to the Editor." The Nation, May 1, 1948. p. 514.

"Limits on the Atomic Bomb: An Interview with Lewis L. Strauss." U.S. News and World Report, March 17, 1950. pp. 28-31.

Lindley, Earnest K. “Facts About the Superbomb.” Newsweek, January 30, 1950. p. 23.

Littell, Robert. "What the Atomic Bomb Would Do to Us." The Reader's Digest 48 (April 1946): 125-129.

McMahon, Brien. "Survival - the Real Issue of Our Times." The Bulletin of Atomic Scientists 8 (August 1952): 173-175.

Moley, Raymond. “An Atomic Balance of Power.” Newsweek, October 10, 1949. p. 96.

"More Scientists Comment on the Soviet Bomb." The Bulletin of Atomic Scientists 5 (November 1949): 323.

"National Affairs." Time, February 13, 1950. p. 15.

"National Affairs." Time, January 30, 1950. p. 11.

“National Affairs." Time, January 16, 1950. p. 19.

"National Affairs." Time, October 10, 1949. p. 7.

"National Affairs." Time, October 3, 1949. p. 7.

"National Affairs." Time, March 29, 1948. p. 21.

"New Defense Against Atomic Atom Bomb." U.S. News and World Report, September 21, 1951. pp. 11-13.

“Optimism on Atomic Bomb." U.S. News and World Report, December 14, 1945. pp. 89-95.

Patterson, Robert P. "We Must Have Military Training—Now!” The Saturday Evening Post, April 26, 1947. p. 26. 
“Peacetime Draft: 6-Month Plan.” U.S. News and World Report, March 28, 1947. p. 13.

"Plan to Revise the Draft." U.S. News and World Report, October 4, 1946. p. 15.

"The President Orders Exploration of the Super Bomb." The Bulletin of Atomic Scientists 6 (March 1950): 66.

"Proffering the Atomic Secret: Security for World as Peace." U.S. News and World Report, November 23, 1945. pp. 11-13.

“The Quarter's Polls.” Public Opinion Quarterly 14 (Summer 1950).

“The Quarter's Polls.” Public Opinion Quarterly 13 (Spring 1949).

“The Quarter's Polls.” Public Opinion Quarterly 11 (Summer 1947).

“The Quarter’s Polls.” Public Opinion Quarterly 11 (Spring 1947).

“The Quarter's Polls.” Public Opinion Quarterly 10 (Fall 1946).

“The Quarter's Polls.” Public Opinion Quarterly 9 (Winter 1945-46).

“The Quarter's Polls.” Public Opinion Quarterly 9 (Fall 1945).

"Question of the Week." U.S. News and World Report, November 2, 1945. p. 48.

"Reassurance on the Atom." U.S. News and World Report, December 21, 1945. p. 27.

Ridenour, Louis N. “The Hydrogen Bomb.” Scientific American 182 (March 1950): $11-15$.

“Science.” Newsweek, October 30, 1950. pp. 58-59.

“Science." Time, May 15, 1950. pp. 74-75.

“Science.” Time, March 6, 1950. pp. 88-89.

“Science.” Time, November 28, 1949. p. 66.

"Secrets of the Atomic Bomb Tests." U.S. News and World Report, May 9, 1947. pp. 24-25.

"Secrets Will Out." The Bulletin of Atomic Scientists 6 (March 1950): 67. 
Seitz, Frederick. "Danger Ahead." The Bulletin of Atomic Scientists 5 (October 1949): 266.

Siemes, Reverend John A. "From Hiroshima: A Report and a Question." Time, February 11, 1946. pp. 26-27.

"Significance of the H-Bomb, and America's Dilemma." Newsweek, February 13, 1950. p. 20.

"The Soviet Announcement." The Bulletin of Atomic Scientists 5 (October 1949): 261.

"The Soviet Bomb." The New Republic, October 3, 1949. p. 5.

Stone, I.F. "Toward World War III." The Nation, February 7, 1948. p. 146.

Taylor, Harold. "Why I Oppose U.M.T.” The Nation, April 17, 1948. p. 410.

Teller, Edward. "Back to the Laboratories." The Bulletin of Atomic Scientists 6 (March 1950): 71.

"To Thwart Russia's Aggression: Message by President Truman to the Congress." U.S. News and World Report, August 5, 1949. pp. 40-41.

“Toward a Climax." Life, October 3, 1949. p. 22.

"Truth About Soviet Air Force: Now the Biggest in the World." U.S. News and World Report, October 21, 1949. pp. 11-13.

Urey, Harold C. "Should America Build the H-Bomb?" The Bulletin of Atomic Scientists 6 (March 1950): 72.

Urey, Harold C. "Needed: Less Witch Hunting and More Work." Bulletin of Atomic Scientists 5 (October 1949): 265.

“U.S. Learns It Can Make the H-Bomb." Life, January 30, 1950. pp. 22-23.

“The U.S.S.R. Has Topflight Science Team.” Life, October 3, 1949. p. 20.

"War and UMT." Newsweek, June 9, 1947. p. 24.

“War Drill for All Youths?” U.S. News and World Report, June 13, 1947. p. 15.

"Week By Week.” The Commonweal, February 17, 1950. p. 499.

“A Week Of Shock and Decision.” Life, February 13, 1950. pp. 36-37. 
"What to do About the A-Bomb." U.S. News and World Report, September 7, 1949. pp. 14-17.

"What to do About A-Bomb Now that Russia Has It." U.S. News and World Report, September 30, 1949. pp. 13-15.

"Why War Scare is Ending: Russia's Shift to Defensive." U.S. News and World Report, July 8, 1949. pp. 11-12.

“Why We Told.” Newsweek, October 3, 1949. p. 18.

“Why We'll Make the H-Bomb.” Newsweek, February 13, 1950. pp. 19-20.

Zeidler, Frank P. "Civil Defense and the Nevada Tests." The Bulletin of Atomic Scientists 8 (August 1952): 204.

Zeidler, Frank P. "Local Government Looks at the Civil Defense Act." The Bulletin of Atomic Scientists 7 (February 1951): 57-58.

\section{SECONDARY SOURCES}

\section{Books:}

Aronson, James. The Press and the Cold War. Indianapolis: The Bobbs-Merrill Company, Inc., 1970.

Appy, Christian G. ed. Cold War Constructions: The Political Culture of United States Imperialism, 1945-1966. Amherst: The University of Massachusetts Press, 2000.

Boyer, Paul. Fallout: A Historian Reflects on America's Half-Century Encounter with Nuclear Weapons. Columbus: Ohio State University Press, 1998.

Boyer, Paul. When Time Shall Be No More. Cambridge, Massachusetts: The Belknap Press of Harvard University Press, 1992.

Boyer, Paul. By the Bomb's Early Light: American Thought and Culture at the Dawn of The Atomic Age. New York: Pantheon Books, 1985.

Eisenberg, Carolyn Woods. Drawing the Line: The American Decision to Divide Germany, 1944-1949. New York: Cambridge University Press, 1996.

Ferrell, Robert H. Harry S. Truman: A Life. Columbia: University of Missouri Press, 1994. 
Fousek, John. To Lead the Free World: American Nationalism and the Cultural Roots of the Cold War. Chapel Hill: University of North Carolina Press, 2000.

Freeland, Richard M. The Truman Doctrine and the Origins of the Cold War. New York: Alfred A. Knopf, 1972.

Friedberg, Aaron L. In the Shadow of the Garrison State: America's Anti-Statism And Its Grand Strategy. Princeton: Princeton University Press, 2000.

Gaddis, John L. We Now Know: Rethinking Cold War History. New York: Clarendon Press, 1997.

Gaddis, John L. Strategies of Containment: A Critical Appraisal of Postwar American National Security Policy. New York: Oxford University Press, 1982.

Gaddis, John L. The United States and the Origins of the Cold War, 1941-1947. New York: Columbia University Press, 1972.

Gardner, Lloyd C. Architects of Illusion: Men and Ideas in American Foreign Policy 1941-1949. Chicago: Quadrangle Books, 1970.

Garwin, Richard L. and Georges Charpak. Megawatts and Megatons: A Turning Point In the Nuclear Age? New York: Alfred A. Knopf, 2001

Hamby, Alonzo L. Man of the People: A Life of Harry S. Truman. New York: Oxford University Press, 1995.

Herken, Gregg. The Winning Weapon: The Atomic Bomb in the Cold War, 1945-1950. New York: Alfred A. Knopf, 1980.

Hogan, Michael J. A Cross of Iron: Harry S. Truman and the Origins of the National Security State, 1945-1954. New York: Cambridge University Press, 1998.

Hogan, Michael J. The Marshall Plan: America, Britain, and the Reconstruction of Western Europe, 1947-1952. New York: Cambridge University Press, 1987.

Holloway, David. Stalin and the Bomb: The Soviet Union and Atomic Energy 19391956. New Haven: Yale University Press, 1994.

Janis, Irving L. and Leon Mann. Decision Making: A Psychological Analysis of Conflict, Choice and Commitment. New York: The Free Press, 1977.

Josephson, Paul R. Red Atom: Russia's Nuclear Power Program from Stalin to Today. New York: W.H. Freeman and Company, 2000. 
Keylor, William R. The Twentieth-Century World: An International History. $4^{\text {th }}$ ed. New York: Oxford University Press, 2001.

Kofsky, Frank. Harry S. Truman and the War Scare of 1948: A Successful Campaign to Deceive the Nation. New York: St. Martin's Press, 1993.

Kolko, Joyce and Gabriel. The Limits of Power: The World and the United States Foreign Policy, 1945-1954. New York: Harper \& Row, Publishers, 1972.

Krugler, David F. The Voice of America and the Domestic Propaganda Battles, 19451953. Columbia: University of Missouri Press, 2000.

Lebow, Richard Ned. Between Peace and War: The Nature of International Crisis. Baltimore and London: The John Hopkins University Press, 1984.

LaFeber, Walter. America, Russia, and the Cold War 1945-1990. $6^{\text {th }}$ ed., New York: McGraw-Hill, Inc., 1991.

Leffler, Melvin P. The Specter of Communism: The United States and the Origins of the Cold War, 1917-1953. New York: Hill and Wang, 1994.

Leffler, Melvin P. A Preponderance of Power: National Security, the Truman Administration and the Cold War. Stanford: Stanford University Press, 1992.

Mastny, Vojtech. The Cold War and Soviet Insecurity: The Stalin Years. New York: Oxford University Press, 1996.

May, Elaine Tyler. Homeward Bound: American Families in the Cold War Era. rev.ed. New York: Basic Books, 1999.

McCagg, Jr., William O. Stalin Embattled 1943-1948. Detroit: Wayne State University Press, 1978.

Merry, Robert W. Taking on the World: Joseph and Stewart Alsop-Guardians of the American Century. New York: Viking Press, 1996.

Offner, Arnold A. Another Such Victory: President Truman and the Cold War 19451953. Stanford: Stanford University Press, 2002.

Paterson, Thomas G. Soviet-American Confrontation: Postwar Reconstruction and the Origins of the Cold War. Baltimore: The John Hopkins University Press, 1973.

Paterson, Thomas G., ed. Cold War Critics: Alternatives to American Foreign Policy in the Truman Years. Chicago: Quadrangle Books, 1971. 
Perry, Mark. Four Stars. Boston: Houghton Mifflin Company, 1989.

Pogue, Forrest C. George C. Marshall: Statesman. New York: Viking, 1987.

Rhodes, Richard. Dark Sun: The Making of the Hydrogen Bomb. New York: Simon \& Schuster, 1995.

Rhodes, Richard. The Making of the Atomic Bomb. New York: Simon \& Schuster, 1986.

Rothschild, Joseph and Nancy M. Wingfield. Return to Diversity: A Political History of East Central Europe Since World War II. $3^{\text {rd }}$ ed. New York: Oxford University Press, 2000.

Steel, Ronald. Walter Lippmann and the American Century. Boston: Little, Brown and Company, 1980.

Szasz, Ferenc Morton. The Day the Sun Rose Twice: The Story of the Trinity Site Nuclear Explosion July 16, 1945. Albuquerque: University of New Mexico Press, 1984.

Taubman, William. Stalin's American Policy: From Entente to Détente to Cold War. New York and London: W.W. Norton \& Company, 1982.

Titus, A. Costandina. Bombs in the Backyard: Atomic Testing and American Politics. Reno \& Las Vegas: University of Nevada Press, 2001.

Ulam, Adam B. Expansion and Coexistence: The History of Soviet Foreign Policy, 1917-67. New York: Frederick A. Praeger, Publishers, 1968.

Vertzberger, Yaacov Y. I. The World in Their Minds: Information Processing, Cognition, and Perception in Foreign Policy Decisionmaking. Stanford: Stanford University Press, 1990.

Wittner, Lawrence S. One World or None: A History of the World Nuclear Disarmament Movement Through 1953. Stanford: Stanford University Press, 1993.

Zubok, Vladislav, and Constantine Pleshakov. Inside the Kremlin's Cold War: From Stalin to Khrushchev. Cambridge: Harvard University Press, 1996.

\section{Unpublished Material:}

Ward, Robert D. "The Movement for Universal Military Training in the United States, 1942-1952.” Ph. D. dissertation, University of North Carolina, 1957. 


\section{Articles:}

Adler, Les K. and Thomas G. Paterson. "Red Fascism: The Merger of Nazi Germany And Soviet Russia in the American Image of Totalitarianism, 1930's-1940's." American Historical Review 75 (April, 1970): 1046-1064.

Costigliola, Frank. "The Nuclear Family: Tropes of Gender and Pathology." Diplomatic History 21 (Spring 1997): 163-83.

Costigliola, Frank. “ 'Unceasing Pressure for Penetration': Gender, Pathology, and Emotion in George Kennan's Formation of the Cold War." Journal of American History 83 (March 1997): 1309-39.

Herring, George C. "Lend-Lease to Russia and the Origins of the Cold War." The Journal of American History 56 (June 1969): 93-114.

Kelly, Timothy and Joseph Kelly. "American Christians and the Discourse of Fear." In Peter Stearns and Jan Lewis, eds. An Emotional History of the United States. New York and London: New York University Press, 1998.

McMahon, Robert J. "Credibility and World Power: Exploring the Psychological Dimensions in Postwar American Policy." Diplomatic History 15 (Fall 1991): 455-71. 